\title{
Abrogation of $\mathrm{BRAF}^{\mathrm{V600E}}$-induced senescence by PI3K pathway activation contributes to melanomagenesis
}

\author{
Liesbeth C.W. Vredeveld, ${ }^{1,5}$ Patricia A. Possik, ${ }^{1,5}$ Marjon A. Smit, ${ }^{1,6}$ Katrin Meissl, ${ }^{1,6}$ \\ Chrysiis Michaloglou, ${ }^{1,6}$ Hugo M. Horlings, ${ }^{2}$ Abderrahim Ajouaou, ${ }^{2}$ Pim C. Kortman, ${ }^{3}$ \\ David Dankort, ${ }^{4,7}$ Martin McMahon, ${ }^{4}$ Wolter J. Mooi, ${ }^{3}$ and Daniel S. Peeper ${ }^{1,8}$ \\ ${ }^{1}$ Division of Molecular Oncology, ${ }^{2}$ Department of Pathology, The Netherlands Cancer Institute, 1066 CX Amsterdam, The \\ Netherlands; ${ }^{3}$ Department of Pathology, VU University Medical Center, 1081 HV Amsterdam, The Netherlands; ${ }^{4}$ Helen Diller \\ Family Comprehensive Cancer Center, Department of Cell and Molecular Pharmacology, University of California at San \\ Francisco, San Francisco, California 94158, USA
}

\begin{abstract}
Human melanocytic nevi (moles) are benign lesions harboring activated oncogenes, including BRAF. Although this oncogene initially acts mitogenically, eventually, oncogene-induced senescence (OIS) ensues. Nevi can infrequently progress to melanomas, but the mechanistic relationship with OIS is unclear. We show here that PTEN depletion abrogates $\mathrm{BRAF}^{\mathrm{V} 600 \mathrm{E}}$-induced senescence in human fibroblasts and melanocytes. Correspondingly, in established murine $\mathrm{BRAF}^{\mathrm{V} 600 \mathrm{E}}$-driven nevi, acute shRNA-mediated depletion of PTEN prompted tumor progression. Furthermore, genetic analysis of laser-guided microdissected human contiguous nevus-melanoma specimens recurrently revealed identical mutations in $B R A F$ or NRAS in adjacent benign and malignant melanocytes. The PI3K pathway was often activated through either decreased PTEN or increased AKT3 expression in melanomas relative to their adjacent nevi. Pharmacologic PI3K inhibition in melanoma cells suppressed proliferation and induced the senescence-associated tumor suppressor $\mathrm{p}^{\mathrm{INK}}{ }^{\mathrm{IB}}$. This treatment also eliminated subpopulations resistant to targeted $\mathrm{BRAF}^{\mathrm{V600E}}$ inhibition. Our findings suggest that a significant proportion of melanomas arise from nevi. Furthermore, these results demonstrate that PI3K pathway activation serves as a rate-limiting event in this setting, acting at least in part by abrogating OIS. The reactivation of senescence features and elimination of cells refractory to BRAF ${ }^{\mathrm{V} 600 E}$ inhibition by PI3K inhibition warrants further investigation into the therapeutic potential of simultaneously targeting these pathways in melanoma.
\end{abstract}

[Keywords: senescence; nevus; melanoma; BRAF ${ }^{\mathrm{V} 600 \mathrm{E}}$; PTEN; AKT; PI3K pathway]

Supplemental material is available for this article.

Received January 12, 2012; revised version accepted April 5, 2012.

Nevi (moles) are benign melanocytic lesions that usually remain permanently growth-arrested for several decades, in spite of the fact that they commonly harbor a mutant allele of BRAF (Pollock et al. 2003) or NRAS (Bauer et al. 2007). The most frequent $B R A F$ mutation observed results in a valine-to-glutamic acid change at position 600 $\left(\mathrm{BRAF}^{\mathrm{V} 600 \mathrm{E}}\right)$, which renders this protein kinase constitutively active (Davies et al. 2002). We showed previously that expression of $\mathrm{BRAF}^{\mathrm{V} 600 \mathrm{E}}$ induces premature senescence in human melanocytes and human diploid fibroblasts (HDF) (Michaloglou et al. 2005). Correspondingly,

\footnotetext{
${ }^{5}$ These authors contributed equally to this work.

${ }^{6}$ These authors contributed equally to this work.

${ }^{7}$ Present address: Department of Biology, McGill University, Montreal, Quebec H3A1B1, Canada.

${ }^{8}$ Corresponding author.

E-mail d.peeper@nki.nl.

Article published online ahead of print. Article and publication date are online at http://www.genesdev.org/cgi/doi/10.1101/gad.187252.112.
}

nevi display several hallmarks of senescence: stable proliferation arrest, increased expression of the CDK4/6 inhibitor p16 ${ }^{\text {INK4A }}$, and induction of senescence-associated $\beta$-galactosidase (SA- $\beta$-Gal) activity (Michaloglou et al. 2005). As this occurs in the absence of gross telomere shortening, we and others have proposed that oncogene-induced senescence (OIS) is an in vivo tumorsuppressive mechanism that prevents melanomagenesis (Bennett 2003; Mooi and Peeper 2006).

The stable proliferative arrest seen in nevi is of high biological and clinical relevance, as it represents a key difference from melanoma, which expands excessively (Mooi and Krausz 2007). It is widely believed that a substantial percentage of melanomas arise from melanocytic nevi (Mooi and Krausz 2007). Indeed, several groups have provided genetic evidence that supports a progression model (Demunter et al. 2001; Bogdan et al. 2003; Yazdi et al. 2003; Dadzie et al. 2009|. From the model outlined above, we and others deduced previously that abrogation 
of OIS of nevus cells may act as a rate-limiting event for melanomagenesis (Bennett 2003; Mooi and Peeper 2006). Favoring this hypothesis, nevi and melanomas are commonly and significantly histologically associated (Stolz et al. 1989; Smolle et al. 1999; Bevona et al. 2003 and references therein). Furthermore, melanomas and nevi are found nonrandomly in close proximity (Smolle et al. 19991.

However, the molecular mechanism underlying malignant transformation from nevus to melanoma is not yet resolved. The primary molecular engine driving melanomagenesis is the activation of the ERK pathway, mainly due to oncogenic mutation of BRAF (Davies et al. 2002; Pollock et al. 2003) or NRAS (Raybaud et al. 1988; van't Veer et al. 1989). Other frequent genetic events include the loss of $C D K N 2 A$ and $A R F$, amplification of CCND1 or CDK4 (Kamb et al. 1994; Nobori et al. 1994; Freeman et al. 2003; Curtin et al. 2005), and, as identified more recently, alterations in MMP8, GRM3, ERBB4, GRIN2A (Palavalli et al. 2009; Prickett et al. 2009, 2011; Wei et al. 2011), and MITF (Garraway et al. 2005; Yokoyama et al. 2011). Loss of $\mathrm{p} 16^{\mathrm{INK} 4 \mathrm{~A}}$ has long been suspected to play a critical role in the abrogation of OIS. However, although its involvement in melanomagenesis is undisputed (Curtin et al. 2005; COSMIC database, http://www.sanger. ac.uk/genetics/CGP/cosmic), and a role in replicative senescence has been reported (Gray-Schopfer et al. 2006), the available evidence supports a redundant role for $\mathrm{p} 16^{\mathrm{INK} 4 \mathrm{~A}}$ in senescence induced by mutant BRAF or NRAS in vitro (Michaloglou et al. 2005; Denoyelle et al. 2006; Haferkamp et al. 2009) and in vivo (Dhomen et al. 2009).

Another common genetic event in melanoma is the activation of the PI3K pathway (Dhawan et al. 2002; Stahl et al. 2004). Elevated AKT activity is observed in $17 \%$ of benign nevi, $43 \%$ of dysplastic nevi, $49 \%$ of primary melanomas, and $77 \%$ of metastatic melanomas, correlating increased PI3K pathway with melanoma progression (Dai et al. 2005). Mutations in PIK3CA are rare in melanoma (Omholt et al. 2006), however, which suggests that other alterations contribute to activation of the pathway. PTEN is functionally lost in the majority of melanomas by either mutation, loss of heterozygosity (LOH) and chromosomal loss, methylation-induced transcriptional silencing, or microRNA-dependent mechanisms (Guldberg et al. 1997; Birck et al. 2000; Zhou et al. 2000; Tsao et al. 2003; Mirmohammadsadegh et al. 2006). Interestingly, concurrent mutation in $B R A F$ and diminished expression of PTEN are common in melanomas (Tsao et al. 2000, 2004; Daniotti et al. 2004; Lin et al. 2008). The PI3K pathway can be activated in melanoma also by increased AKT3 activity owing to overexpression or mutation (Stahl et al. 2004; Davies et al. 2008). Furthermore, AKT3 was shown to cooperate with $\mathrm{BRAF}^{\mathrm{V} 600 \mathrm{E}}$ in the transformation of murine melanocytes in vitro through mechanisms that involve phosphorylation of $\mathrm{BRAF}^{\mathrm{V} 600 \mathrm{E}}$ by AKT3 (Cheung et al. 2008).

Here, we put to the test the hypothesis that abrogation of $\mathrm{BRAF}^{\mathrm{V} 600 \mathrm{E}}$-induced senescence contributes to melanomagenesis and set out to identify the key players that are mechanistically involved.

\section{Results}

PTEN depletion abrogates BRAF ${ }^{V 600 E}$-induced senescence in cultured human fibroblasts

To investigate the possible role of PI3K pathway activation in evasion of $\mathrm{BRAF}^{\mathrm{V} 600 \mathrm{E}}$-induced senescence, we first focused on any effect of PTEN loss. As expected, PTEN depletion by two independent shRNAs from primary human fibroblasts resulted in activation of a critical downstream effector, AKT (as measured by P-AKT) (Fig. 1A). Consistent with our previous results (Michaloglou et al. 2005), ectopic expression of BRAF ${ }^{\mathrm{V} 600 \mathrm{E}}$ in HDF induced a robust cell cycle arrest, which was accompanied by an increase in p16 ${ }^{\mathrm{INK} 4 \mathrm{~A}}$ (Fig. 1A). Importantly, depletion of PTEN effectively abrogated BRAF ${ }^{\mathrm{V} 600 \mathrm{E}}$-induced senescence (Fig. 1B,C). We corroborated the participation of PI3K pathway activation in abrogation of $\mathrm{BRAF}^{\mathrm{V} 600 \mathrm{E}}$-induced senescence by ectopic expression of either wild-type or activated PIK3CA or activated AKT1 in independent HDF strains. This also effectively prevented $\mathrm{BRAF}^{\mathrm{V} 600 \mathrm{E}}$-induced senescence in fibroblasts (Supplemental Fig. 1A-F), indicating a causal role for this signaling route in the growth inhibitory action of $\mathrm{BRAF}^{\mathrm{V} 600 \mathrm{E}}$, consistent with previous results (CourtoisCox et al. 2006). The increase in cell number seen in proliferation assays was not due to decreased cell death (which is not induced in HDF by $\mathrm{BRAF}^{\mathrm{V} 600 \mathrm{E}}$ ) (data not shown), but reflected decreased senescence and increased DNA replication as a function of PI3K activation, as evident from SA- $\beta$-Gal activity and bromodeoxyuridine (BrdU) incorporation assays (Fig. 1C; Supplemental Fig. 1B,C).

\section{PTEN depletion abrogates BRAF ${ }^{V 600 E}$-induced senescence in cultured human melanocytes}

Given the prominent role of $\mathrm{BRAF}^{\mathrm{V} 600 \mathrm{E}}$ in nevi and melanomas and the frequent reduction of PTEN levels seen in melanomas (Tsao et al. 2000, 2004; Daniotti et al. 2004; Lin et al. 2008), we set out to determine the role of PTEN in the senescence program of primary human melanocytes in the context of oncogenic BRAF. These melanocytes were isolated from neonatal foreskins and characterized for melanocytic markers and the ability to undergo OIS (Michaloglou et al. 2005). Of note, similar to primary mammary epithelial cells (Brenner et al. 1998), primary melanocytes appear to be under selective pressure to lose $\mathrm{p} 16^{\mathrm{INK} 4 \mathrm{~A}}$ during in vitro propagation (Bennett 2003). To avoid spontaneous mutations in $\mathrm{p} 16^{\mathrm{INK} 4 \mathrm{~A}}$ or undefined genes, these experiments were performed with p16 ${ }^{\text {INK4A }}$-depleted melanocytes (which still undergo $\mathrm{BRAF}^{\mathrm{V} 600 \mathrm{E}}$-induced senescence), but similar results were obtained with wild-type melanocytes (data not shown).

Consistent with previous results (Michaloglou et al. 2005; Denoyelle et al. 2006), BRAF ${ }^{\mathrm{V} 600 \mathrm{E}}$ efficiently triggered senescence in melanocytes (Fig. 2A-C). shRNAmediated PTEN depletion, however, prevented BRAF ${ }^{\mathrm{V} 600 \mathrm{E}}$ cells from undergoing OIS. This was illustrated by increased cell proliferation, a significant rise in DNA replication, and decreased SA- $\beta$-Gal activity relative to BRAF $^{\mathrm{V} 600 \mathrm{E}}$-expressing melanocytes (Fig. 2A-C). 
A

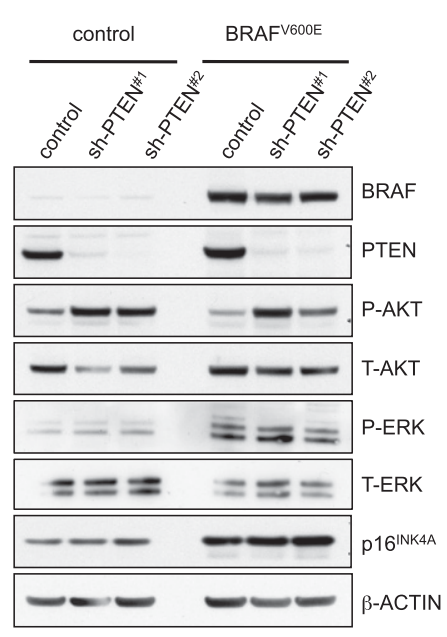

B

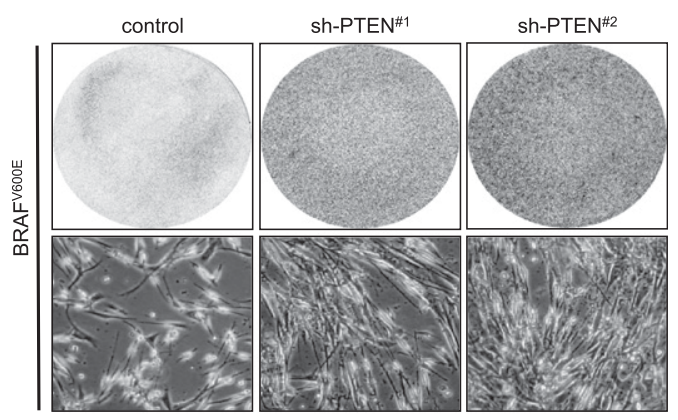

C

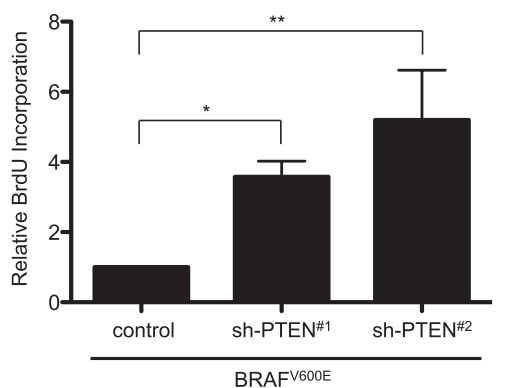

Figure 1. PTEN depletion abrogates $B R A F^{\mathrm{V} 600 E}$-induced senescence in cultured human fibroblasts. TIG3 HDF stably expressing one of two nonoverlapping PTEN shRNAs (\#1 or \#2) as well as hTERT (to avoid confounding effects due to replicative senescence; hTERT does not interfere with $\mathrm{BRAF}^{\mathrm{V} 600 \mathrm{E}}$-induced senescence) were transduced with $\mathrm{BRAF}^{\mathrm{V} 600 \mathrm{E}}$-encoding retrovirus and selected for integration of the construct. Empty vectors were used as controls. $(A)$ Samples were analyzed by Western blot for the indicated proteins $8 \mathrm{~d}$ post-infection. $\beta$-Actin served as a loading control. $(B)$ Samples were seeded at equal densities and fixed and stained 8 d post-infection. $(C)$ Samples were analyzed for BrdU incorporation $3 \mathrm{~d}$ post-infection. Data are represented as mean with standard deviation (SD) (paired ratio two-tailed $t$-test; $\left.\left[{ }^{\star}\right] P=0.0001 ;{ }^{* \star}\right] P=0.0006$ ).

As expected, $\mathrm{BRAF}^{\mathrm{V} 600 \mathrm{E}}$ expression resulted in strong ERK activation, while PTEN depletion induced phosphorylation of AKT, which was further enhanced by $\mathrm{BRAF}^{\mathrm{V} 600 \mathrm{E}}$ (Fig. 2D). Up-regulation of P-AKT was a common feature among BRAF mutant melanoma cell lines but did not always correlate to PTEN levels, consistent with the idea that PTEN-independent signaling also feeds into AKT (Supplemental Fig. 2A). Less expected was the observation that $\mathrm{BRAF}^{\mathrm{V} 600 \mathrm{E}}$ strongly suppressed the accumulation of AKT3 in human melanocytes. This was at least partially restored in PTEN-depleted melanocytes evading OIS. Of note, we were unsuccessful in overexpressing PI3K or AKT family members (either wildtype or activated forms) in melanocytes, most likely because of toxicity. This is consistent with (but does not formally explain) the observation that mutational activation of PIK3CA is rare in melanoma but more frequent in several other human tumor types and suggests that reduction of PTEN dosage is not identical to an increase in PI3K signaling.

Although consistent with the hypothesis that abrogation of OIS contributes to melanomagenesis, the results above do not necessarily reflect the physiologic situation. Indeed, it is conceivable that PTEN deficiency in vivo occurs after the acquisition of the $\mathrm{BRAF}^{\mathrm{V} 600 \mathrm{E}}$ mutation rather than prior to it. In an attempt to better mimic such a scenario, we first introduced $\mathrm{BRAF}^{\mathrm{V} 600 \mathrm{E}}$ to trigger melanocyte senescence. Subsequently, melanocytes were transduced with lentivirus targeting PTEN. Upon its depletion, we again observed a consistent bypass of OIS (Fig. 2E; Supplemental Fig. 2B). Although this effect was moderate in vitro, such a senescence override is likely to be relevant in vivo. We conclude, therefore, that PTEN depletion leads to abrogation of $\mathrm{BRAF}^{\mathrm{V} 600 \mathrm{E}}$-induced senescence in human melanocytes.

\section{Abrogation of BRAF $F^{V 600}$-induced senescence by PTEN depletion is dose-dependent}

While some studies show that PTEN deficiency induces senescence in fibroblasts (Chen et al. 2005), it appears that its expression levels play an essential role: Slight differences in PTEN expression affect cell survival and proliferation (Alimonti et al. 2010). To address the importance of PTEN expression in melanocytes, we titrated lentiviruses expressing sh-PTEN in the presence or absence of BRAF ${ }^{\mathrm{V} 600 \mathrm{E}}$.

The bypass of $\mathrm{BRAF}^{\mathrm{V} 600 \mathrm{E}}$-induced senescence upon PTEN depletion correlated with PTEN expression levels, as judged by the ability to incorporate BrdU and SA- $\beta-G a l$ activity (Fig. 3A-C). Importantly, determination of cell numbers revealed that there was an optimum: Too much 
Vredeveld et al.

A

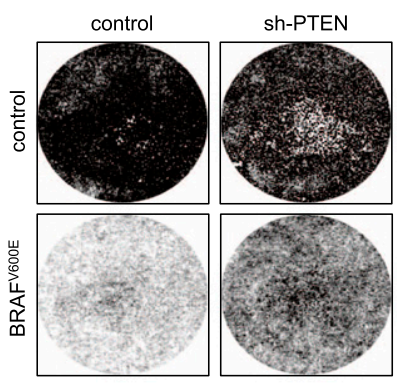

C

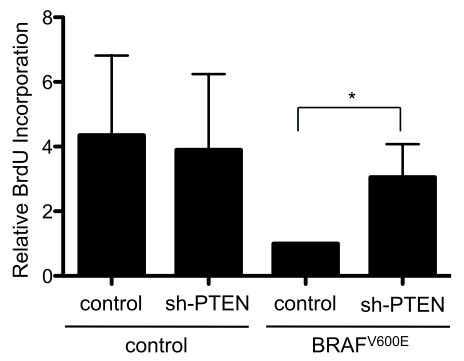

E

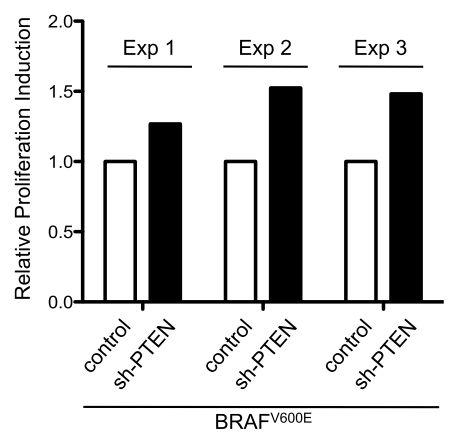

B

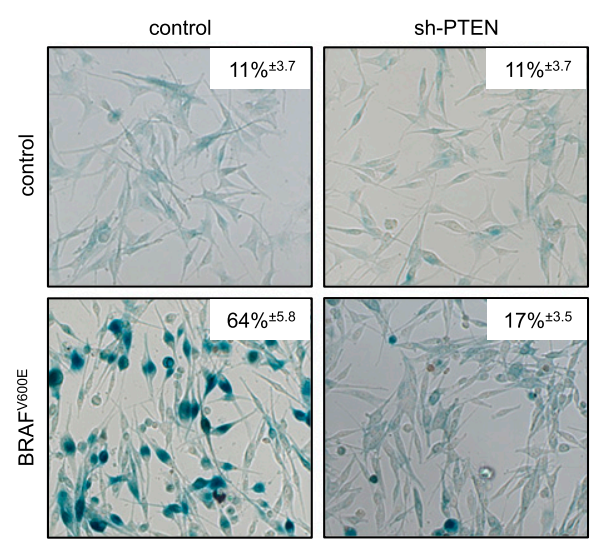

D

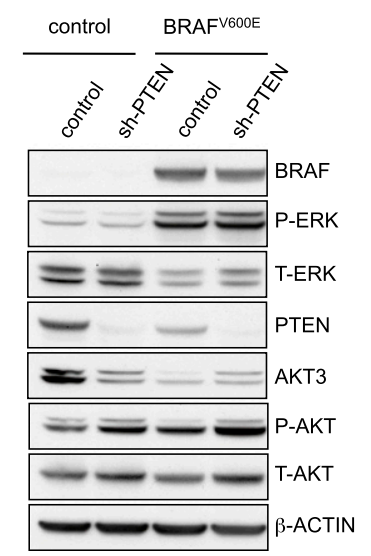

Figure 2. PTEN depletion abrogates $B R A F^{\mathrm{V} 600 E}$-induced senescence in cultured human melanocytes. $(A)$ Primary human melanocytes stably expressing sh-p $16^{\mathrm{INK} 4 \mathrm{~A}}$ and either control or sh-PTEN (\#1) were transduced with control or BRAF ${ }^{\mathrm{V} 600 \mathrm{E}}$-encoding lentivirus and pharmacologically selected for successful integration of the construct. Empty vectors were used as controls. Samples were seeded at equal densities and fixed and stained $15 \mathrm{~d}$ post-infection. (B) Samples were fixed and analyzed for SA- $\beta$-Gal activity $15 \mathrm{~d}$ post-infection. Data are represented as percentage of cells $\pm \mathrm{SD}$ (paired two-tailed $t$-test; $P=0.0001$ for the bottom panel). (C) Samples were analyzed for BrdU incorporation $15 \mathrm{~d}$ post-infection. Data are represented as mean $\pm \mathrm{SD}$ (paired ratio two-tailed $t$-test; $\left.\left[{ }^{\star}\right] P=0.0001\right) .(D)$ Samples were analyzed by Western blot for protein expression as indicated. $\beta$-Actin served as a loading control. $(E)$ Melanocytes stably expressing sh-p $16^{\mathrm{INK} 4 \mathrm{~A}}$ were first transduced with $\mathrm{BRAF}^{\mathrm{V} 600 \mathrm{E}}$-encoding lentivirus, subsequently transduced with either control or shPTEN, and analyzed for BrdU incorporation $8 \mathrm{~d}$ post-infection. The relative ratios of three independent experiments are illustrated in the graph. Statistical analysis was performed by a paired ratio two-tailed $t$-test; $P=0.025$.

PTEN depletion no longer resulted in a net increase in cell number, because of cytotoxic effects (Fig. 3D; data not shown). Too little PTEN depletion, on the other hand, failed to impair the senescence program. Thus, there was a window of PTEN expression that allowed $\mathrm{BRAF}^{\mathrm{V} 600 \mathrm{E}_{-}}$ expressing melanocytes to evade senescence. Furthermore, whereas $\mathrm{BRAF}^{\mathrm{V} 600 \mathrm{E}}$ overexpression in melanocytes triggered up-regulation of the senescence-associated tumor suppressor $\mathrm{p} 15^{\mathrm{INK} 4 \mathrm{~B}}$, cells bypassing OIS down-regulated expression of $\mathrm{p} 15^{\mathrm{INK} K \mathrm{~B}}$. This correlated with both the dosage of PTEN and BrdU incorporation (Fig. 3A,B). We conclude, therefore, that there is an optimal window of PTEN expression allowing BRAF ${ }^{\mathrm{V} 600 \mathrm{E}}$-expressing melanocytes to abrogate OIS bypass: Too high levels do not allow for proliferation, whereas too low levels are cytotoxic.

Acute in vivo PTEN depletion in BRAF ${ }^{V 600 E}$-expressing nevi drives tumor formation

To validate the role of PTEN in the context of BRAF $\mathrm{V}^{\mathrm{V} 600 \mathrm{E}}$ in an in vivo setting, we made use of a knock-in $\mathrm{BRAF}^{\mathrm{V} 600 \mathrm{E}}$ mouse model that allows for melanocyte-specific and inducible expression of $\mathrm{BRAF}^{\mathrm{V} 600 \mathrm{E}}$ (Tyr::CreER; BRaf ${ }^{\mathrm{CA}}$ ) (Dankort et al. 2009). Upon 4-OHT (4-hydroxytamoxifen) treatment, these mice develop nevus-like lesions that are characterized by hyperplasia of melanocytes in the dermis and hair follicles with the presence of melanophages (Fig. 4A; Dankort et al. 2009). This represents a physiologically relevant setting to investigate whether, also in mice, PTEN depletion triggers proliferation of $\mathrm{BRAF}^{\mathrm{V} 600 \mathrm{E}}$-expressing melanocytes. To this end, we injected a lentivirus carrying sh-PTEN into these lesions. This commonly led to tumor formation at the sites of injection (Fig. 4B; Supplemental Fig. 3A). Focal pigmentation areas (dendritic melanocytes and melanophages) were observed and confirmed by H\&E staining (Fig. 4A,C) and electron microscopy (data not shown). Histologically, these tumors consisted predominantly of oval to elongated cells with oval monochromatic nuclei and ill-defined pale cytoplasm. A minority of cells contained microgranular melanin pigment, which highlighted dendritic processes in some. 
A

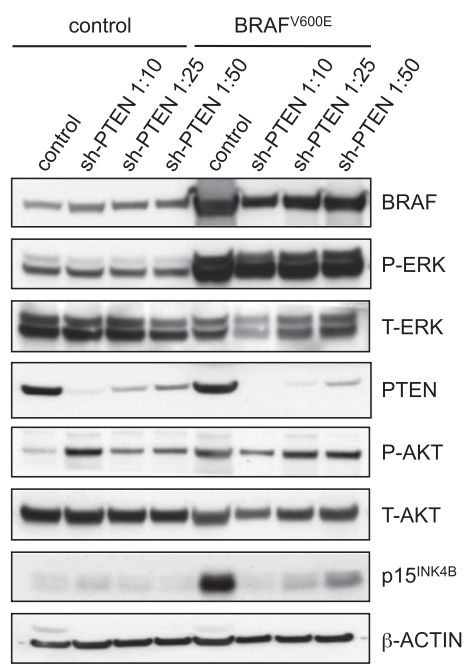

Scattered groups of larger, polygonal, pigmented cells were seen as well. Necrosis was absent. The tumor cells infiltrated diffusely into the cutaneous and subcutaneous tissues, including striated muscle.

Of note, the lesions developed within the first month after injection of sh-PTEN virus, but subsequently slowed down without progressing further. Indeed, mitotic figures were noted at that stage only occasionally. Mice that had received control vector showed no lesions at all or very small lesions. Confirming BRAF ${ }^{\mathrm{V} 600 \mathrm{E}}$ expression in these sh-PTEN-induced lesions, rearrangement of the $B R a f^{C A}$ allele was detected by PCR (Supplemental Fig. 3B). Lesions of mice treated with sh-PTEN showed enrichment of the $\mathrm{BRAF}^{\mathrm{V} 600 \mathrm{E}}$-encoding allele compared with control-treated mice, suggesting that cells expressing $\mathrm{BRAF}^{\mathrm{V} 600 \mathrm{E}}$ constitute the lesions. These results indicate that PTEN depletion can cause $\mathrm{BRAF}^{\mathrm{V} 600 \mathrm{E}}$-expressing nevus cells to resume proliferation, providing a time window for tumorigenic expansion in vivo.
Figure 3. Abrogation of $\mathrm{BRAF}^{\mathrm{V} 600 \mathrm{E}}$-induced senescence by PTEN depletion is dose-dependent. Primary human melanocytes stably expressing sh-p16 ${ }^{\mathrm{INK} 4 \mathrm{~A}}$ and either control or sh-PTEN (\#1) were transduced with control or BRAF ${ }^{\mathrm{V} 600 \mathrm{E}}$. encoding lentivirus and selected for integration of the construct. Empty vectors were used as controls. (A) Samples were analyzed by Western blot for protein expression as indicated. $\beta$-Actin served as a loading control. $(B)$ Samples were analyzed for BrdU incorporation $15 \mathrm{~d}$ post-infection. Data are represented as mean $\pm \mathrm{SD}$ (oneway ANOVA/Bonferroni's multiple comparison test; $P<0.05)$. $(C)$ Samples were fixed and analyzed for SA- $\beta$-Gal activity $15 \mathrm{~d}$ post-infection. Data are represented as percentage of cells \pm SD (one-way ANOVA/Tukey's multiple comparison). For both $B$ and $C$, BRAF $^{\mathrm{V} 600 \mathrm{E}}$ sh-PTEN1:10 and BRAF $^{\mathrm{V} 600 \mathrm{E}}$ sh-PTEN1:25 samples are significantly different from $\mathrm{BRAF}^{\mathrm{V} 600 \mathrm{E}}$ controls $(P<0.05)$. (D) Samples were seeded at equal densities and fixed and stained $15 \mathrm{~d}$ post-infection. Crystal violet staining was extracted and quantified; similar results were obtained in duplicate experiments.

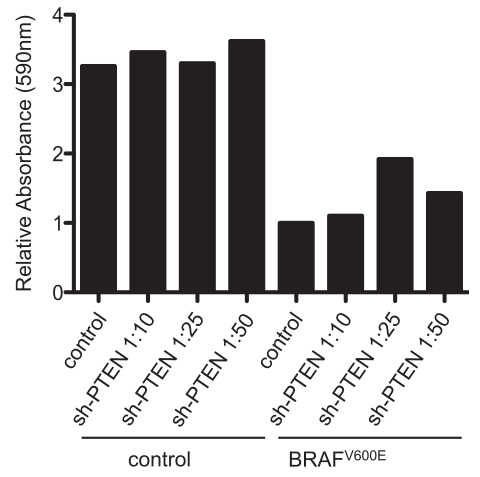

Significant conservation of BRAF and NRAS mutations during progression from nevi to melanomas

We next wished to extend our findings obtained in vitro and in mice to humans. Specifically, we examined the possibility that also in human melanocytic lesions, reduction in PTEN levels, resulting in activation of the PI3K pathway, represents a rate-limiting step for the outgrowth of BRAF ${ }^{\mathrm{V} 600 \mathrm{E}}$-expressing melanocytes. Therefore, we investigated a series of 21 human tissue sections with nevi in direct contiguity with melanomas. Because a nevus-to-melanoma progression model predicts conservation of the driver mutation, we first examined whether the cells of the nevus and the contiguous melanoma in each specimen were clonally related. Genetic evidence has been presented previously in support of a progression model (NRAS, KRAS, and BRAF mutations [Demunter et al. 2001; Yazdi et al. 2003; Dadzie et al. 2009] and LOH of 9p21 markers [Bogdan et al. 2003]), but, importantly, no 
Vredeveld et al.

A
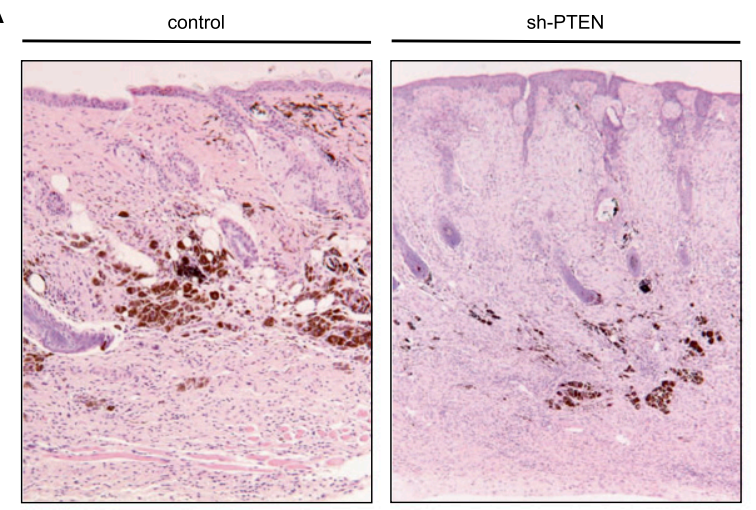

C

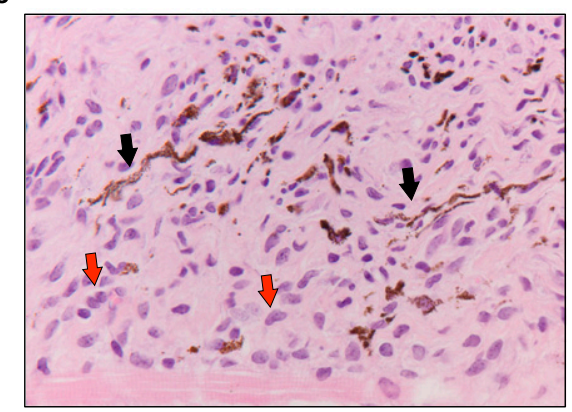

B
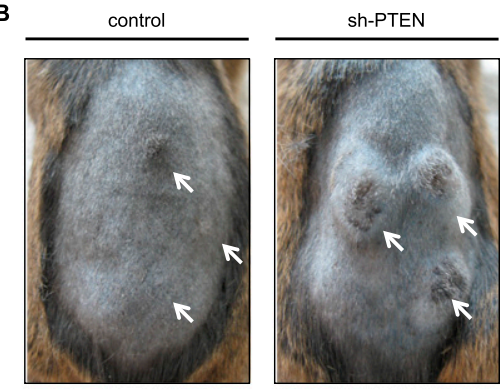

Figure 4. Acute in vivo PTEN depletion in $\mathrm{BRAF}^{\mathrm{V} 600 \mathrm{E}}$-expressing nevi drives tumor formation. $(A)$ H\&E staining of mouse skin injected with lentivirus carrying either control or shRNA constructs. The sh-PTEN-injected lesion is more cellular and larger; both lesions show focal melanotic pigmentation indicative of the melanocytic origin. $(B)$ Photographs of mice bearing tumors 18.5 wk after intradermal injection of sh-PTEN-carrying lentivirus. Adult mice received a sublethal total body irradiation (5 Gy) $3 \mathrm{~d}$ prior to lentivirus application to reduce an immune response eradicating virus-infected cells. shRNA targeting PTEN (sh-PTEN\#3) or empty vector control were delivered by intradermal injection of lentivirus into the dorsal skin of 4-OHT-treated Tyr::CreER; BRaf ${ }^{C A}$ mice. Arrows indicate sites of injections. $(C)$ High-power micrograph of melanocytic tumor of a sh-PTEN-injected mouse showing a population of plump to elongated cells (red arrows), some of which are laden with melanin pigment, highlighting the characteristic melanocytic dendrites (black arrows).

statistical analysis was used to rule out random cooccurrence of mutations within these lesions.

We first attempted to identify the "driver" mutations in the nevus and melanoma cell compartments. We focused on the likely suspects $B R A F$ and NRAS, as they are most commonly activated in melanomas as well as nevi. Seventeen specimens were considered suitable for laser capture microdissection, after which the mutational status of $B R A F$ exon 15 and NRAS exon 3 (in which most activating mutations reside) (Forbes et al. 2006; COSMIC database, http://www.sanger.ac.uk/genetics/CGP/cosmic) was analyzed by genomic DNA PCR amplification and sequencing. In addition, areas with normal tissue in these sections were microdissected in all cases and processed along with the nevi and melanomas as controls for positive identification of the wild-type NRAS and BRAF alleles and for excluding contamination problems or the occurrence of polymorphisms.

We found the common $B R A F^{T 1799 A}$ mutation (encoding $\mathrm{BRAF}^{\mathrm{V} 600 \mathrm{E}}$ ) in eight samples, seven of which showed co-occurrence of this mutation in both the nevi and their flanking melanomas (Fig. 5A, red bars; Supplemental Table 1). Interestingly, in one sample, we identified a rare $B R A F^{T G 1799-1800 A A}$ double mutation /also encoding $\mathrm{BRAF}^{\mathrm{V} 600 \mathrm{E}}$ ) in the melanoma as well as the associated nevus (Fig. 5B-D; Supplemental Fig. 4A-D for detailed information). In addition, activating NRAS mutations were detected in four samples, two of which showed cooccurrence in nevi and their contiguous melanomas. The presence of a BRAF or NRAS mutation in three melanomas but not in their contiguous nevi suggests that either the lesions within these specimens are clonally unrelated or the lesions harbor driver mutations other than those located in BRAF exon 15 and NRAS exon 3, with mutation in $B R A F$ or NRAS occurring later, during melanoma progression. Finally, we identified four specimens with wild-type BRAF exon 15 and NRAS exon 3 sequences in all lesions. We cannot exclude, however, that some of these results are false negatives due to the very small lesion size in some cases.

To evaluate the statistical significance of these findings, we collected from the COSMIC database (http:// www.sanger.ac.uk/genetics/CGP/cosmic) the percentages of each mutation identified in the above-described specimens (Fig. 5E) and calculated for all cases the probability that identical mutations in nevi and melanomas could have occurred by chance (Supplemental Table 1). For each mutation identified in the 17 specimens, we calculated the expected frequencies of random co-occurrence in nevi and matched melanomas (i.e., Fig. 5A, gray bars labeled "Expected") and compared these with the observed co-occurrence frequency obtained from actual 
A

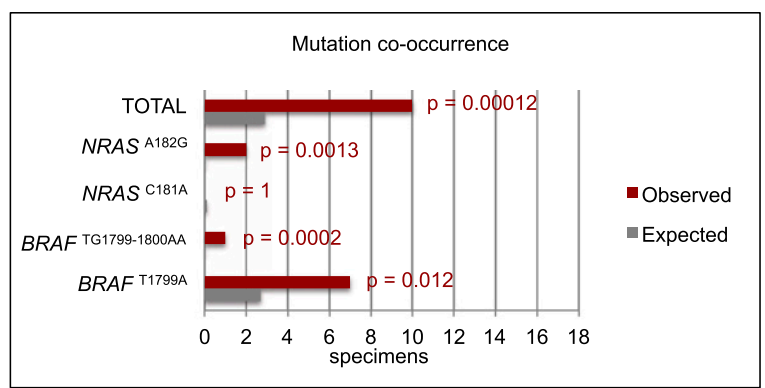

B

C
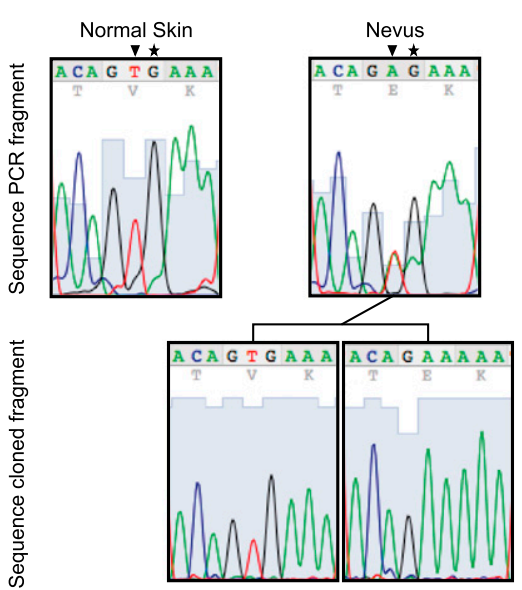

D

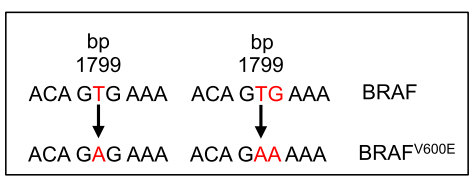

E

\begin{tabular}{|c|c|c|c|c|}
\hline $\begin{array}{c}\text { COSMIC } \\
\text { database }\end{array}$ & $\begin{array}{c}\text { BRAF } \\
\text { T1799A }\end{array}$ & $\begin{array}{c}\text { BRAF } \\
\text { TG1799- } \\
1800 A A\end{array}$ & $\begin{array}{c}\text { NRAS } \\
\text { C181A }\end{array}$ & $\begin{array}{c}\text { NRAS } \\
\text { A182G }\end{array}$ \\
\hline Nevus & $41.7 \%$ & $0.4 \%$ & $9.0 \%$ & $3.6 \%$ \\
\hline Melanoma & $38.4 \%$ & $0.3 \%$ & $7.2 \%$ & $8.6 \%$ \\
\hline
\end{tabular}

Figure 5. Significant conservation of $B R A F$ and $N R A S$ mutations during progression from nevi to melanomas. (A) Bar graph representing expected and observed frequencies of melanomas and their associated nevi harboring identical $B R A F$ and NRAS mutations in nevi and contiguous melanomas. Seventeen specimens were suitable for laser capture microdissection, after which the mutational status of $B R A F$ exon 15 and NRAS exon 3 (in which most activating mutations reside) was analyzed by genomic DNA PCR amplification and sequencing. Red bars (Observed) represent the mutational status observed for $B R A F$ and NRAS in 17 nevi that are directly contiguous to melanomas. Gray bars (Expected) represent the calculated percentages of random (co-)occurrence. For statistical analysis, we carried out the "one-sample test" for proportions, with the null hypothesis being that the mutations occurred randomly. The "two-sided alternative test" was used to calculate $P$-values, which were $<0.05$ for the BRAF ${ }^{\mathrm{T} 1799 \mathrm{~A}}, B R A F^{\mathrm{TG} 1799-1800 \mathrm{AA}}$, and NRAS ${ }^{\mathrm{A} 182 \mathrm{G}}$ mutations, indicating that it is highly unlikely that the observed co-occurrence of these mutations (in red) has arisen due to chance. See Supplemental Table 1 for details. $(B)$ A rare $B R A F$ double mutation co-occurring in the nevus and the adjacent melanoma. Chromatograms of $B R A F$ exon 15 PCR fragments amplified from genomic DNA of laser-microdissected normal skin, nevus, and melanoma and of a fibroblast cell line as a control. Arrowheads indicate nucleotide thymine 1799 in BRAF, which is often found mutated to an adenine, and asterisks indicate nucleotide guanine 1800 , which is rarely found mutated to an adenine. $(C)$ Chromatograms of cloned PCR fragments encompassing BRAF exon 15 show either the wild-type allele or the allele with the double mutation. (D) Schematic over-

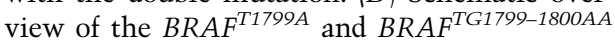
mutations, both encoding $\mathrm{BRAF}^{\mathrm{V} 600 \mathrm{E}}$. (E) To perform the statistical calculations, percentages of $B R A F^{\mathrm{T} 1799 \mathrm{~A}}, B R A F^{\mathrm{TG} 1799-1800 \mathrm{AA}}, N R A S^{\mathrm{C} 181 \mathrm{~A}}$, and $N R A S^{\mathrm{A} 182 \mathrm{G}}$ mutations were extracted from the COSMIC database (http://www. sanger.ac.uk/genetics/CGP/cosmic) (Forbes et al. 2006). Melanomas and benign melanocytic nevi originating from skin were selected, excluding acral, mucosal, ocular, and genital origin; spitz; and blue nevi, as these types were not included in our specimen panel.

mutational analysis (Fig. 5A, red bars labeled "Observed"). The predicted chance of random co-occurrence based on the percentages from the COSMIC database (http://www.sanger.ac.uk/genetics/CGP/cosmic) was then compared with the observed results of the mutational analysis. We found co-occurrence of $B R A F$ and NRAS mutations in flanking nevi and melanomas that was statistically significant in 10 out of 17 specimens $(P$-value $<0.05)$, arguing that at least a considerable proportion of melanomas in this series are clonally related to their contiguous nevi.

\section{Decrease in PTEN and increase in AKT3 and P-AKT expression in melanomas relative to their contiguous nevi}

To investigate the role of PTEN reduction and PI3K pathway activation in human melanomagenesis in vivo, we analyzed the relative expression levels of PTEN by immunohistochemical staining of our series of contiguous nevus-melanoma specimens. As we had noted that $\mathrm{BRAF}^{\mathrm{V} 600 \mathrm{E}}$ suppresses AKT3 accumulation in cultured melanocytes (Fig. 2D), we also included immunostaining for this factor as well as for P-AKT. Five out of 21 samples displayed reduced PTEN immunostaining in the melanoma compared with the associated nevus, including the sample with the rare $B R A F$ double mutation (Fig. 6A-C; Table 1; Supplemental Fig. 5A-F). Conversely, an increase in AKT3 staining in the melanoma compared with the nevus was detected in nine specimens (Fig. 6D-F; Table 1; Supplemental Fig. 5G-I). In two specimens, both PTEN reduction and AKT3 increase were seen. Correspondingly, in the majority of the specimens analyzed, we detected induction of P-AKT in the melanoma relative to the nevus (Fig. 6G-I; Table 1). These analyses reveal recurrent activation of the PI3K pathway in melanomas 


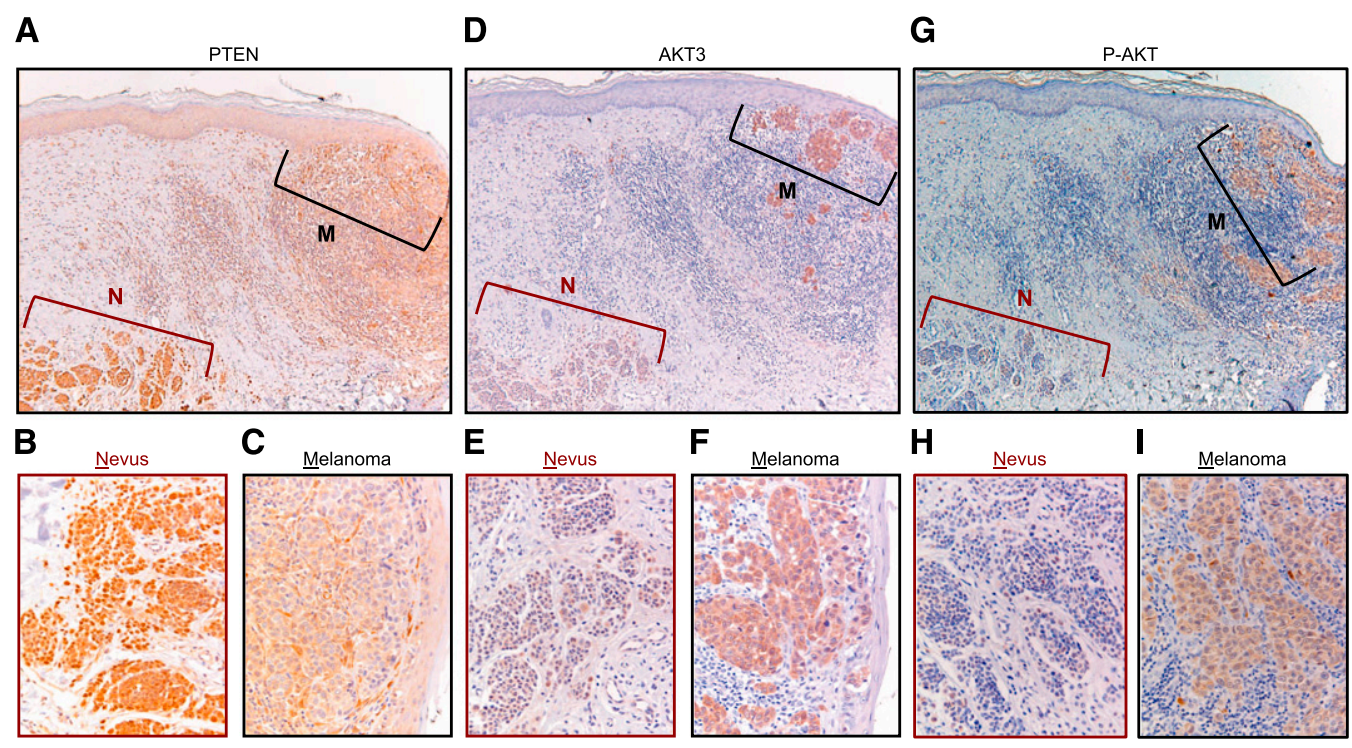

Figure 6. Decrease in PTEN and increase in AKT3 and P-AKT expression in melanomas relative to their contiguous nevi. Representative immunohistochemical stainings of consecutive sections of a contiguous nevus-melanoma specimen with PTEN, AKT3, and P-AKT antibodies. Both nevus and melanoma compartments harbor the BRAF ${ }^{\mathrm{T} 1799 \mathrm{~A}}$ mutation, as determined by laser capture microdissection and sequence analysis. The melanoma compartment $(\mathrm{M})$ exhibits clearly weaker PTEN $(A-C)$ and stronger AKT3 $(D-F)$ and P-AKT $(G-I)$ immunostaining compared with the nevus compartment $(\mathrm{N}) . B, E$, and $H$ show higher magnifications of the nevus, and $C, F$, and $I$, show higher magnifications of the melanoma. The cell-rich area underneath the melanoma compartment comprises mainly infiltrating lymphocytes.

relative to their contiguous nevi, with alterations in PTEN and AKT accounting for 12 out of 21 cases.

\section{Pharmacologic PI3K inhibition induces cell cycle arrest in melanoma cells}

In view of the strong evidence linking PTEN reduction and PI3K pathway activation to melanoma, PI3K is receiving increasing interest as a possible therapeutic target. As our results indicate that activation of the PI3K pathway overrides $\mathrm{BRAF}^{\mathrm{V} 600 \mathrm{E}}$-induced senescence and represents a frequent event during melanomagenesis, we next investigated whether PI3K pathway inhibition could reactivate aspects of the senescence program in melanoma cells. We treated $\mathrm{BRAF}^{\mathrm{V} 600 \mathrm{E}}$ melanoma cell lines with increasing concentrations of Pi-103, an inhibitor of PI3K and mTOR kinases. Cells treated with Pi-103 showed a profound decline in proliferative capacity, as measured by cell proliferation and BrdU incorporation assays (Fig. 7A,B), consistent with previous data (Marone et al. 2009). Correspondingly, the expression levels of $\mathrm{p} 15^{\mathrm{INK} 4 \mathrm{~B}}$ increased upon Pi-103 treatment (Fig. 7C). Occasionally, but not consistently, we observed induction of SA- $\beta$-Gal activity (data not shown), suggesting that PI3K inhibition reactivates senescence incompletely, perhaps owing to the large number of genetic alterations typically seen in melanoma.

\section{Pharmacologic PI3K inhibition enhances cytotoxicity of BRAF ${ }^{V 6 O O E}$ inactivation}

An exciting recent clinical development is the availability of mutant BRAF-specific inhibitors. Although, initially, dramatic responses are seen in melanoma patients, eventually, most of them show tumor progression. Intense investigations have revealed that tumor relapse occurs owing to a variety of resistance mechanisms, some of them implicating activation of the PI3K pathway as a key player in resistance to BRAF or MEK inhibition (Shao and Aplin 2010; Atefi et al. 2011; Paraiso et al. 2011). Therefore, there is a dire need to find combination therapy to delay or avoid resistance. In view of the results obtained for pharmacologic PI3K inhibition, we explored the possible therapeutic benefit of combining PI3K and $\mathrm{BRAF}^{\mathrm{V} 600 \mathrm{E}}$ inhibition in melanoma cells.

As expected, treatment with Pi-103 and PLX4720 (a BRAF ${ }^{\mathrm{V} 600 \mathrm{E}}$ inhibitor) inhibited the activity of AKT and ERK, respectively (Fig. 7D). More importantly, Pi-103 treatment profoundly cooperated with $\mathrm{BRAF}^{\mathrm{V} 600 \mathrm{E}}$ inhibition in dose response curves (Fig. 7E; Supplemental Fig. $6 \mathrm{~A})$. Interestingly, whereas melanoma cells mainly arrested upon Pi-103 treatment, combination with PLX4720 induced cell death, as demonstrated by the cooperative induction of cleaved caspase 3 (Fig. 7F; Supplemental Fig. 6B). This was accompanied by the neutralization of p $15^{\text {INK4B }}$ induction by Pi-103, suggesting cross-talk between these two pathways (Fig. 7C).

We noted that the response to PLX4720 treatment varied among melanoma cells, and in some cases, a population of cells survived even high doses of this drug (Fig. 7G). We therefore treated also these resistant cell lines with increasing concentrations of PLX4720 and analyzed the possible additive effect of Pi-103. Interestingly, combined inhibition of the PI3K and BRAF ${ }^{\mathrm{V} 600 \mathrm{E}}$ kinases efficiently eliminated the population of resistant melanoma cells (Fig. 7G; Supplemental Fig. 6C). We 
Table 1. PI3K pathway activation and mutational status of BRAF and NRAS in a series of contiguous human nevus-melanoma specimens

\begin{tabular}{|c|c|c|c|c|c|}
\hline Number & $\begin{array}{l}\text { PTEN reduction } \\
\text { or loss in melanoma } \\
\text { relative to nevus }\end{array}$ & $\begin{array}{l}\text { AKT3 induction } \\
\text { in melanoma } \\
\text { relative to nevus }\end{array}$ & $\begin{array}{l}\text { P-AKT induction } \\
\text { in melanoma } \\
\text { relative to nevus }\end{array}$ & $\begin{array}{l}\text { Mutation in nevus } \\
\text { and melanoma } \\
\text { conserved }\end{array}$ & Mutation \\
\hline 1 & V & $\mathrm{V}$ & $\mathrm{V}$ & $\mathrm{V}$ & Both $\mathrm{N}$ and $\mathrm{M} B R A F^{\mathrm{T} 1799 \mathrm{~A}}$ \\
\hline 2 & $\mathrm{~V}$ & & $\mathrm{~V}$ & $\mathrm{~V}$ & Both $\mathrm{N}$ and $\mathrm{M} B R A F^{\mathrm{TG} 1799-1800 \mathrm{AA}}$ \\
\hline 3 & $\mathrm{~V}$ & & V & $?$ & $\begin{array}{l}\text { Both } \mathrm{N} \text { and } \mathrm{M} B R A F \text { exon } 15 \\
\text { and NRAS exon } 3 \text { wild type }\end{array}$ \\
\hline 4 & $\mathrm{~V}$ & $\mathrm{~V}$ & V & $?$ & $\begin{array}{l}\text { Both } \mathrm{N} \text { and } \mathrm{M} B R A F \text { exon } 15 \\
\text { and } N R A S \text { exon } 3 \text { wild type }\end{array}$ \\
\hline 5 & $\mathrm{~V}$ & & ND & $\mathrm{V}$ & Both $\mathrm{N}$ and $\mathrm{M} B R A F^{\mathrm{T} 1799 \mathrm{~A}}$ \\
\hline 6 & & $\mathrm{~V}$ & V & ND & \\
\hline 7 & & $\mathrm{~V}$ & $\mathrm{~V}$ & $?$ & $\begin{array}{l}\text { Both } \mathrm{N} \text { and } \mathrm{M} B R A F \text { exon } 15 \\
\text { and } N R A S \text { exon } 3 \text { wild type }\end{array}$ \\
\hline 8 & & $\mathrm{~V}$ & $\mathrm{~V}$ & $\mathrm{~V}$ & Both $\mathrm{N}$ and $\mathrm{M} B R A F^{\mathrm{T} 1799 \mathrm{~A}}$ \\
\hline 9 & & $\mathrm{~V}$ & $\mathrm{~V}$ & $?$ & $\begin{array}{l}\text { Both } \mathrm{N} \text { and } \mathrm{M} B R A F \text { exon } 15 \\
\text { and NRAS exon } 3 \text { wild type }\end{array}$ \\
\hline 10 & & $\mathrm{~V}$ & V & & $\mathrm{N} B R A F^{\mathrm{T} 1799(\mathrm{wt})}, \mathrm{M} B R A F^{\mathrm{T} 1799 \mathrm{~A}}$ \\
\hline 11 & & $\mathrm{~V}$ & & $\mathrm{~V}$ & Both $\mathrm{N}$ and $\mathrm{M} N R A S^{\mathrm{A} 182 \mathrm{G}}$ \\
\hline 12 & & $\mathrm{~V}$ & ND & ND & \\
\hline 13 & & & $\mathrm{~V}$ & $\mathrm{~V}$ & Both $\mathrm{N}$ and $\mathrm{M} B R A F^{\mathrm{T} 1799 \mathrm{~A}}$ \\
\hline 14 & & & $\mathrm{~V}$ & $\mathrm{~V}$ & Both $\mathrm{N}$ and $\mathrm{M} N R A S^{\mathrm{A} 182 \mathrm{G}}$ \\
\hline 15 & & & V & $\mathrm{V}$ & Both $\mathrm{N}$ and $\mathrm{M} B R A F^{\mathrm{T} 1799 \mathrm{~A}}$ \\
\hline 16 & & & V & ND & \\
\hline 17 & & & V & & $\mathrm{N} N R A S^{\mathrm{A} 182(\mathrm{wt})} \mathrm{M} N R A S^{\mathrm{A} 182 \mathrm{G}}$ \\
\hline 18 & & & $\mathrm{~V}$ & $\mathrm{~V}$ & Both $\mathrm{N}$ and $\mathrm{M} B R A F^{\mathrm{T} 1799 \mathrm{~A}}$ \\
\hline 19 & & & & ND & \\
\hline 20 & & & ND & & $\mathrm{N} N R A S^{\mathrm{C} 181(\mathrm{wt})}, \mathrm{M} N R A S^{\mathrm{C} 181 \mathrm{~A}}$ \\
\hline 21 & & & ND & $\mathrm{V}$ & Both $\mathrm{N}$ and $\mathrm{M} B R A F^{\mathrm{T} 1799 \mathrm{~A}}$ \\
\hline
\end{tabular}

(V) Present; (ND) not determined because specimen was not suitable for laser capture microdissection. BRAF exon 15 and NRAS exon 3 are wild-type sequences; the remainder of the gene was not sequenced. (?) The driver mutation is unknown; (N) nevus; (M) melanoma.

conclude from these results that while BRAF and PI3K pathway activation collaborate in melanomagenesis, pharmacologic PI3K inhibition reactivates senescence features and enhances the cytotoxicity of targeted mutant BRAF inhibition.

\section{Discussion}

To understand the molecular basis of melanomagenesis, it is imperative to identify the genetic changes that facilitate the different steps in progression from normal melanocytes to nevus and melanoma. A large proportion of melanomas harbor alterations in both the BRAF and $P T E N$ genes, leading to their constitutive activation and inactivation, respectively. As we and others have previously postulated that abrogation of OIS in human nevi contributes to melanomagenesis, we here put to the test the hypothesis that reduction of PTEN plays a ratelimiting role in the progression from nevus to melanoma.

We employed four independent settings for this investigation: cultured human fibroblasts, cultured human melanocytes, a murine nevus model, and human contiguous nevus-melanoma specimens. First, we determined whether down-regulation of PTEN affects the senescence program that is elicited by $\mathrm{BRAF}^{\mathrm{V} 600 \mathrm{E}}$ in vitro. In both primary human fibroblasts and melanocytes, PTEN silencing abolished $\mathrm{BRAF}^{\mathrm{V} 600 \mathrm{E}}$-induced senescence. These results are in agreement with and extend models pre- viously proposed by us and others. For instance, senescent neurofibromas initiate a negative feedback loop in response to oncogenic stress, which inhibits AKT activation and results in the induction of senescence (CourtoisCox et al. 2006). Furthermore, activation of the PI3K pathway by expression of myristoylated AKT1 attenuates RAS-induced senescence (Kennedy et al. 2011). These results suggest that this mechanism is conserved across cell types and shared among different OIS triggers. Hence, the abolishment of OIS by activation of the PI3K pathway may play a role also in tumor types other than melanoma.

In human tissue sections, it has been shown that normal melanocytes and most nevi exhibit PTEN expression, which is down-regulated in approximately a third of primary melanomas and becoming even more pronounced in melanoma metastases (Zhou et al. 2000; Whiteman et al. 2002; Tsao et al. 2003). This has led to the idea that PTEN reduction may be involved in melanoma progression rather than initiation (Whiteman et al. 2002). We analyzed PTEN expression in human contiguous nevus-melanoma specimens to investigate its role in melanoma initiation. By determining the mutational status of BRAF and NRAS in the benign and malignant melanocytic lesions within these specimens, we first investigated whether the nevi that are in direct contiguity with melanomas were clonally related. Indeed, we found co-occurrence of several different mutations in nevi and their associated melanomas. This includes the 
Vredeveld et al.

A

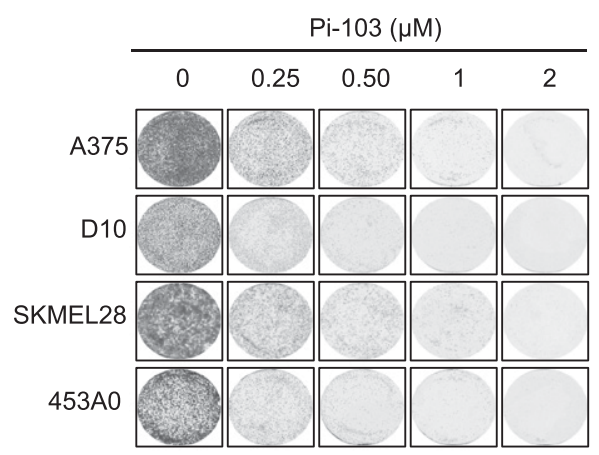

B

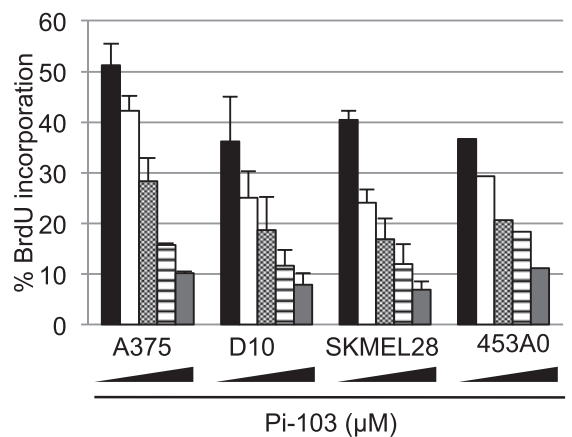

C

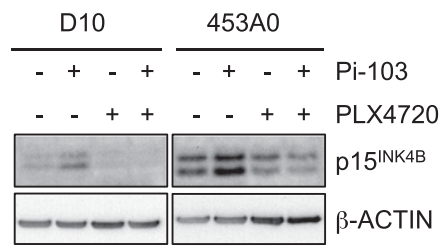

D

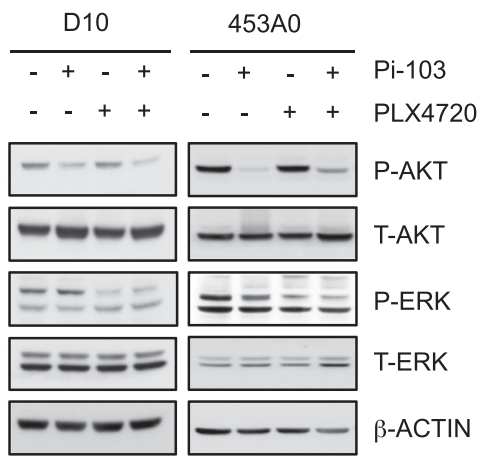

E

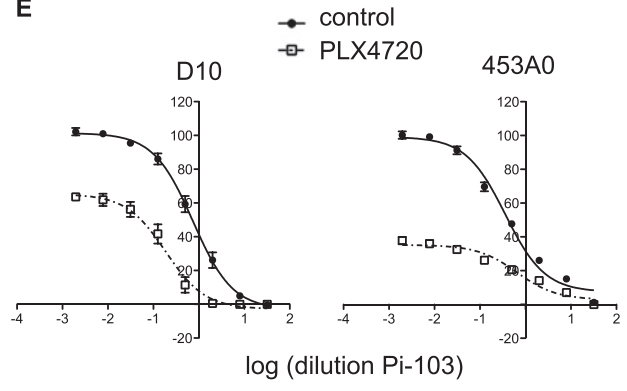

F
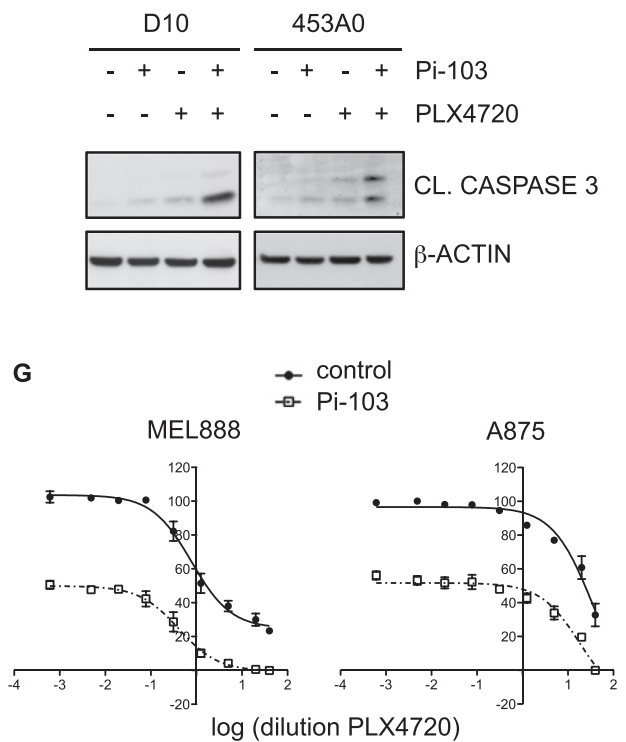

Figure 7. PI3K inhibition induces cell cycle arrest in melanoma cells and enhances cytotoxicity of BRAF ${ }^{\mathrm{V} 600 \mathrm{E}}$ inhibition. Melanoma cell lines were treated with Pi-103 and/or PLX4720. (A) Samples were kept in medium containing Pi-103 for $7 \mathrm{~d}$ and fixed and stained with crystal violet. $(B)$ Samples were analyzed for BrdU incorporation $4 \mathrm{~d}$ after treatment with increasing concentrations of Pi-103 (0.25, $0.5,1$, and $2 \mu \mathrm{M}$ ). Error bars represent SEM (standard error of the mean) of three independent experiments. For 453A0 melanoma cells, a representative experiment is shown. $(C)$ Samples were analyzed by Western blotting for p15 $5^{\mathrm{INK} 4 \mathrm{~B}} 2 \mathrm{~d}$ after treatment with $0.25 \mu \mathrm{M}$ Pi103 and/or $1 \mu \mathrm{M}$ PLX4720. $\beta$-Actin served as a loading control. (D) Melanoma cell lines were treated with $0.5 \mu \mathrm{M}$ Pi-103 and/or $2 \mu \mathrm{M}$ PLX4720 for $4 \mathrm{~h}$. Samples were analyzed by Western blotting for the indicated proteins. $\beta$-Actin served as a loading control. (E) Melanoma cell lines were treated with a dilution series of Pi-103 either alone or in combination with the BRAF ${ }^{\mathrm{V} 600 \mathrm{E}}$ inhibitor PLX4720 at a concentration of $3 \mu \mathrm{M}(\mathrm{D} 10)$ or $1 \mu \mathrm{M}(453 \mathrm{~A} 0)$ for $3 \mathrm{~d}$. Total cell numbers were determined with a cell titer blue assay. The $Y$-axis represents the percentage of living cells. (F) Cells were treated with $0.25 \mu \mathrm{M}$ Pi-103 and/or $1 \mu \mathrm{M}$ PLX4720 for $1 \mathrm{~d}$ (D10) or $3 \mathrm{~d}$ (453A0). Samples were analyzed by Western blotting for cleaved caspase 3. Apoptotic cells in the supernatant were included in the analysis. $\beta$-Actin served as a loading control. $(G)$ Cells were treated with a dilution series of PLX4720 either alone or in combination with $0.5 \mu M$ Pi-103. Total cell numbers were determined with a cell titer blue assay. The Y-axis represents the percentage of living cells. 
$B R A F^{\mathrm{T} 1799 \mathrm{~A}}$ mutation that is commonly found in both nevi and melanomas but was found co-occurring in our data set in a significantly higher number of cases than expected by chance. Furthermore, we found rare mutations (NRAS $S^{C 181 A}$ and BRAF $F^{T G 1799-1800 A A}$ ) co-occurring in adjacent nevi and melanomas that are highly unlikely to have occurred independently. Although this is not formal proof, these results strongly suggest that at least a proportion of melanomas emerge from nevi.

More than half of the lesions we analyzed displayed activation of the PI3K pathway, as judged by loss of PTEN or gain of AKT3 immunopositivity in the melanoma compared with the nevus compartment. Of note, PTEN levels were reduced but appeared to be not completely shut down. This is consistent with our in vitro PTEN RNAi results and suggests a window for PTEN reduction that allows for melanoma development, in agreement with observations on PTEN dosage in cellular senescence and tumor development by others (Chen et al. 2005; Alimonti et al. 2010). As expected, in most of these cases, this was accompanied by increased P-AKT staining in the melanoma compartment. The observation that identical $B R A F$ and NRAS mutations are present in both the nevi and flanking melanomas (at least in 10 out of 17 cases), with concomitant PTEN reduction or AKT activation in the melanoma, is compatible with a model in which $B R A F / N R A S$ mutations precede the PTEN/AKT alterations. This is further supported by our in vitro observation that senescent human melanocytes expressing BRAF $^{\mathrm{V} 600 \mathrm{E}}$ are able to re-enter the cell cycle upon PTEN depletion. Together, our results suggest that not only in vitro, but also in lesions in vivo, activation of the PI3K pathway contributes to the abrogation of the OIS program of human melanocytes, thereby promoting the progression of nevi to melanomas. Clearly, although diminished PTEN expression or increased AKT3 production in melanomas was seen in roughly half of the cases, other pathways are likely to contribute to melanoma progression as well. We propose that alterations at several levels in the PI3K pathway represent a common feature of progression from nevus to melanoma.

We also observed that AKT3 expression levels were down-regulated upon $\mathrm{BRAF}^{\mathrm{V} 600 \mathrm{E}}$ expression in human melanocytes. This is consistent with the previous suggestion that AKT3 is the critical AKT isoform in melanoma cell lines (Stahl et al. 2004) and that overexpression of activated AKT3 enhances anchorage-independent growth of melanoma cells (Cheung et al. 2008). Conversely, specific inhibition of AKT3 has been reported to induce apoptosis and inhibit the tumorigenic capacity of melanoma cells in a xenograft model (Stahl et al. 2004). Although they do not rule out contributions by the other AKT family members, our in vitro and in vivo data are consistent with these observations and support a prominent role of AKT3 in melanomagenesis.

Our finding that PTEN depletion and consequent activation of the PI3K pathway abrogates $\mathrm{BRAF}^{\mathrm{V} 600 \mathrm{E}}$. induced senescence is in agreement with and extends previous data on two BRAF ${ }^{\mathrm{V} 600 \mathrm{E}}$ mouse models. Dhomen et al. (2009) showed that the induction of $\mathrm{BRAF}^{\mathrm{V} 600 \mathrm{E}}$ in melanocytes results in senescent melanocytes displaying elevated SA- $\beta$-Gal activity, low Ki67 expression, and formation of (blue) nevi. After a year, half of these mice developed melanoma, presumably by acquiring additional (yet to be defined) mutations. When the $\mathrm{BRAF}^{\mathrm{V}}{ }^{600 \mathrm{E}}$ nevuscarrying mice were bred onto a $\mathrm{p} 16^{\mathrm{INK} 4 \mathrm{~A}}$-null background, they produced more tumors, which developed earlier, but nonetheless, these mice continued to develop nevi (Dhomen et al. 2009). This is consistent with the mosaic pattern of $\mathrm{p} 16^{\mathrm{INK} 4 \mathrm{~A}}$ immunopositivity frequently seen in human nevi (Michaloglou et al. 2005) and the observation that $\mathrm{p} 16^{\mathrm{INK} 4 \mathrm{~A}}$-deficient individuals have nevi in addition to an increased propensity to develop melanoma (Pavel et al. 2003), arguing that also $\mathrm{p} 16^{\mathrm{INK} 4 \mathrm{~A}}$-independent mechanisms contribute to melanomagenesis. Goel et al. (2009) observed similar features in melanocytes residing in the skin of $\mathrm{BRAF}^{\mathrm{V} 600 \mathrm{E}}$ transgenic mice, including increased levels of $\mathrm{p} 16^{\mathrm{INK} 4 \mathrm{~A}}, \mathrm{p} 53$, and PTEN and elevated SA- $\beta$-Gal activity. Consistent with our model, transgenic $\mathrm{BRAF}^{\mathrm{V} 600 \mathrm{E}}$ mice that develop melanoma strongly upregulate P-AKT levels (Goel et al. 2009).

Also, Dankort et al. (2009) found murine benign melanocytic hyperplasia driven by an endogenous $\mathrm{BRAF}^{\mathrm{V} 600 \mathrm{E}}$ encoding allele. These lesions were highly stable and failed to progress to melanoma for at least up to 20 mo. However, upon simultaneous activation of $\mathrm{BRAF}^{\mathrm{V} 600 \mathrm{E}}$ and genetic inactivation of PTEN, mice quickly developed metastatic melanoma (Dankort et al. 2009). In our in vivo nevus injection model, we also observed cooperation between $\mathrm{BRAF}^{\mathrm{V} 600 \mathrm{E}}$ expression and PTEN depletion in tumor formation, in accordance with Dankort et al. (2009). We used the same conditional BRAF ${ }^{\mathrm{V} 600 \mathrm{E}}$ mouse model, but instead of concomitant induction of mutant $B R A F$ expression and PTEN depletion, we first allowed the mouse to develop nevus-like lesions, which were later treated with sh-PTEN-carrying lentivirus. This strategy allowed us to analyze the order of events and demonstrate that tumors can emerge from $\mathrm{BRAF}^{\mathrm{V} 600 \mathrm{E}}$-arrested lesions in vivo in a PTEN-dependent manner. We cannot rule out that PTEN depletion in stromal cells contributed to this effect. In aggregate, these results support a model in which mutant BRAF and subsequent activation of the PI3K pathway cooperate in melanomagenesis in cultured melanocytes, in murine nevus cells, and in human lesions, with PTEN reduction and PI3K/AKT activation serving, at least in part, to abrogate OIS.

In recent years, several groups have detected senescence biomarkers in several preneoplastic lesions in mice and humans (Kuilman et al. 2010). Commonly, an initial "driver" mutation-either the activation of an oncogene or the loss of a tumor suppressor allele-triggers the establishment of a benign lesion. After this initial phase of cell proliferation, a senescence program is executed, causing the termination of tumor expansion. Only upon the emergence of additional tumorigenic alterations can malignant progression occur. OIS is now widely considered to represent a bona fide tumor suppressor mechanism, acting alongside cell death programs. We believe, therefore, that the field is now entering a second phase, in which we need to delineate the fundamental mechanistic 
aspects of OIS. As we show here, the nevus-melanoma model is ideally suited to unmask at least some of the key players involved. Similarly, BRAF ${ }^{\mathrm{V} 600 \mathrm{E}}$-driven nevus models in zebrafish and mice allow for the identification of melanoma progression genes (Ceol et al. 2011; Karreth et al. 2011). The factors and pathways identified in this way will likely be relevant for other tumor settings as well, as OIS is seen in many tissue types /Collado and Serrano 2010). One question that is particularly relevant in this context is the cell of origin within the nevus-or similar benign lesions, for that matter-that gives rise to the tumor. Is it a fully senescent cell that somehow acquired a secondary mutation, a cell that has stalled halfway through the senescence program, or perhaps a rare senescent (nevus) cell with special (stem cell) properties? This and related questions can be addressed in advanced animal models engineered for lineage tracing.

The critical role for the PI3K pathway in melanoma development may be explored for the development of more effective therapeutic approaches. Our results predict that inhibitors of the PI3K pathway may restrain the expansion of tumors with mutations in $B R A F$ at least in part through restoration of OIS features, a concept that is receiving increasing interest (Nardella et al. 2011). Furthermore, in agreement with previous data (Shao and Aplin 2010; Atefi et al. 2011; Paraiso et al. 2011), we show that inhibition of PI3K can enhance the cytotoxicity of targeted $\mathrm{BRAF}^{\mathrm{V} 600 \mathrm{E}}$ inhibition. In particular, the observation that a PI3K inhibitor can eliminate melanoma cells that resist killing by a $\mathrm{BRAF}^{\mathrm{V} 600 \mathrm{E}}$ inhibitor is of obvious interest and merits further investigation.

Finally, the elucidation of the pathobiology of nevi will increase our understanding of the role of OIS in melanomagenesis and may identify biomarkers that allow a better distinction from melanoma in problem cases. There is a need to identify senescence biomarkers in benign lesions such as nevi; in particular, factors that do not merely accompany OIS, but contribute to the execution of the program. Most markers currently used, such as SA$\beta$-Gal, are associated with the process but likely do not contribute to rate-limiting steps. Identification of new biomarkers is important not only to deepen our understanding of the role of OIS (abrogation) in tumorigenesis, but also for translation of fundamental findings to the clinic; for example, to create new diagnostic opportunities. Indeed, some nevi are difficult or impossible to distinguish with certainty from melanomas and vice versa. We show here that there is a common activation of the PI3K pathway in situ comparing nevi with their contiguous melanomas. These results merit further investigation into the possibility of using biomarkers like PTEN reduction and increases in AKT3 and P-AKT to allow a better distinction between nevi and melanomas in difficult cases.

\section{Materials and methods}

\section{Cell culture and viral transduction}

The HDF cell lines TIG3 and HCA2 (coexpressing the ecotropic receptor and hTERT) as well as Phoenix and HEK293T cells were maintained in DMEM (Gibco) supplemented with 9\% fetal bovine serum (Greiner Bio-One), $2 \mathrm{mM}$ glutamine, $100 \mathrm{U} \mathrm{mL}^{-1}$ penicillin, and $0.1 \mathrm{mg} \mathrm{mL}^{-1}$ streptomycin (all Gibco). The HDF cell line IMR90 (expressing the ecotropic receptor, hTERT, and shRNA for p16 ${ }^{\mathrm{INK} 4 \mathrm{~A}}$ ) was maintained in MEM + Earle's salts (Gibco) containing all supplements mentioned above and nonessential amino acids, $0.15 \%$ sodium bicarbonate, and $1 \mathrm{mM}$ sodium pyruvate (all Gibco). Human melanocytes were isolated from the epidermis of neonatal foreskins (Michaloglou et al. 2005) and maintained in Medium 254 (Cascade Biologicals) supplemented with melanocyte growth supplement (HMGS, Cascade Biologicals), $100 \mathrm{U} \mathrm{mL}^{-1}$ penicillin, and $0.1 \mathrm{mg} \mathrm{mL}^{-1}$ streptomycin (Gibco). Melanoma cell lines (A375, D10, SKMEL28, 453A0, MEL888, and A875) were maintained in DMEM supple-

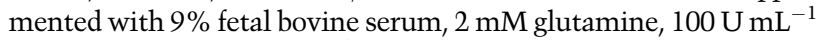
penicillin, and $0.1 \mathrm{mg} \mathrm{mL}^{-1}$ streptomycin.

Retroviral transductions were performed using Phoenix cells as producers. Retrovirus production employing Phoenix cells was performed as described (http://www.stanford.edu/group/ nolan/retroviral_systems/phx.html). For production of lentivirus, HEK293T cells were refreshed with complete medium containing $25 \mathrm{mM}$ chloroquine, transfected with $8 \mu \mathrm{g}$ of lentiviral construct and $3 \mu \mathrm{g}$ of each of the helper plasmids pMDLglpRRE, pHCMV-G, and pRSVrev and washed and refreshed in complete medium after $6 \mathrm{~h}$. Lentivirus was frozen and diluted for transduction. For TIG3, HCA2, and IMR90 cell proliferation assays, cells were transduced with shRNA- or cDNA-encoding retrovirus and checked for successful proviral integration (by puromycin selection or GFP expression). Cells were plated at equal densities, subsequently transduced with $\mathrm{BRAF}^{\mathrm{V} 600 \mathrm{E}}$-encoding retrovirus, and selected (Blasticidin). DNA replication was measured by incubating cells for $3 \mathrm{~h}$ with BrdU 3 $\mathrm{d}$ post-infection. Cells were also seeded at equal numbers and fixed and stained with crystal violet, which was extracted by incubation with $10 \%$ acetic acid, and relative absorbance was measured with a TECAN infinite M200 scanner $8 \mathrm{~d}$ post-infection. Samples were harvested for Western blot analysis $8 \mathrm{~d}$ post-infection. Activity of SA- $\beta$-Gal was also measured $8 \mathrm{~d}$ post-infection (SA- $\beta$-Gal staining kit, Cell Signaling). Melanocytes were transduced with shRNA- or cDNA-encoding lentivirus, cultured for 1 wk with Medium 254 supplemented with HMGS-2 (-PMA, Cascade Biologicals), and subsequently transduced with $\mathrm{BRAF}^{\mathrm{V} 600 \mathrm{E}}$-encoding lentivirus and subjected to Blasticidin selection. Cells were seeded at equal numbers, analyzed for BrdU incorporation, fixed and stained with crystal violet, analyzed for SA- $\beta$-Gal activity, and harvested for Western blot analysis $15 \mathrm{~d}$ post-infection. Alternatively, cells were first transduced with $\mathrm{BRAF}^{\mathrm{V} 600 \mathrm{E}}$-encoding lentivirus, selected for $1 \mathrm{wk}$ with Blasticidin, and subsequently transduced with sh-PTEN-encoding lentivirus. Cells were analyzed $8 \mathrm{~d}$ post-infection for BrdU incorporation and Western blot.

\section{Plasmids}

pRS PURO-sh-PTEN(\#1 and \#2), pMX $_{\text {GFP-PIK3CA }}{ }^{\text {(wt, }}$ K545, R1047, CAAX), and PMSCV BLAST $^{-B R A F}{ }^{\mathrm{V} 600 \mathrm{E}}$ were used for retroviral transduction. KH1 $1_{\mathrm{GFP}}$-sh-p $16^{\mathrm{INK} 4 \mathrm{~A}}, \mathrm{KH} 1_{\mathrm{GFP}}$-sh-PTEN/\#1 and $\# 3)$, and HIV-CSCG ${ }_{\text {BLAST }}-$ BRAF $^{\mathrm{V} 600 \mathrm{E}}$ were used for lentiviral transductions. Corresponding empty vectors were used as controls. Sequences for sh-PTEN are described in the Supplemental Material.

\section{Antibodies}

Antibodies used for Western blot were against BRAF (sc5284, Santa Cruz Biotechnology), PTEN (sc-7974, Santa 
Cruz Biotechnology), AKT3 (\#4059, Cell Signaling), phospho-Ser 473-AKT (\#9271, Cell Signaling), AKT1/2/3 (sc-8312, Santa Cruz Biotechnology), p16 ${ }^{\mathrm{INK} 4 \mathrm{~A}}$ (JC8, Immunologic), p15 $5^{\mathrm{INK} 4 \mathrm{~B}}$ (sc-612, Santa Cruz Biotechnology), p42/p44 (\#9102, Cell Signaling), phospho-p42/p44 (\#9106, Cell Signaling), cleaved caspase 3 (Asp175, Cell Signaling), and $\beta$-actin (AC-74 and A5316, Sigma).

\section{In vivo administration of lentivirus}

The dorsal skin of Tyr::CreER; BRaf ${ }^{C A}$ mice (Dankort et al. 2009) was treated with 4-OHT ( $20 \mathrm{mg} \mathrm{mL}^{-1}$ in EtOH) each second day during the first week after birth. Adult mice received a sublethal total body irradiation (5 Gy) 3 d prior to lentivirus application. shRNA targeting PTEN (sh-PTEN\#1 and sh-PTEN\#3) was delivered by intradermal injection of lentivirus into the dorsal skin of 4-OHT-treated Tyr::CreER; BRaf ${ }^{C A}$ mice. The animal experiments were performed following local and international regulations and ethical guidelines and have been authorized by the local experimental animal committee at The Netherlands Cancer Institute. PCR detection of $B R A F$ allele rearrangements was performed as described (Dankort et al. 2007).

\section{Immunohistochemistry}

Twenty-one formalin-fixed paraffin-embedded human specimens harboring nevi in direct contiguity with melanomas were immunostained for PTEN (clone 6H2.1, DAKO), AKT3 (HPA026441, Sigma-Aldrich), and P-AKT (Ser 473) (736E11, Cell Signaling), as previously described (Michaloglou et al. 2005).

\section{Laser capture microdissection and mutation analysis}

Contiguous nevus-melanoma specimens were sectioned (8 $\mu \mathrm{M})$ on P.A.L.M. pen membrane slides (Microlaser Technologies), which were pretreated according to the manufacturer's instructions with UV and poly-L-lysine, then deparaffinized and stained with hematoxyline. Laser capture microdissection was used to isolate normal tissue, nevus cell groups, and melanoma cell groups, which were identified by pathologist W.J. Mooi, based on consecutive H\&E sections. Genomic DNA was isolated with QIAamp DNA microkit (Qiagen). PCR conditions (TaqPlus Precision PCR system, Stratagene) and primers for PCRs for BRAF exon 15 and NRAS exon 3 are described in the Supplemental Material. PCR products were sequenced using the BigDye Terminator cycle sequencing kit (Applied Biosystems) and an ABI 3730 automated capillary sequencer.

\section{Drug treatments}

Melanoma cell lines were treated with indicated concentrations of Pi-103 (Echelon Biosciences) and/or PLX4720 (Selleck). For dose response curves, samples were measured after $3 \mathrm{~d}$ of treatment with a cell titer blue assay (Promega), and fluorescence was measured with a TECAN infinite M200 scanner. For proliferation assays, cells were either analyzed for BrdU incorporation $4 \mathrm{~d}$ after treatment or seeded at equal densities and fixed and stained with crystal violet $7 \mathrm{~d}$ after treatment. Samples were harvested for Western blot analysis on the indicated days.

\section{Acknowledgments}

We thank N. Armstrong and M.L. Yurda for statistical analysis; Ji-Ying Song for scientific support; R. Kortlever, M. Voorhoeve, and K. Berns for kindly providing constructs; T. Kuilman for critical reading of the manuscript; and all members of the Peeper laboratory for their valuable input. This work was supported by a Melanoma Research Alliance grant to D.D. and M.M., grants from the Dutch Cancer Society (KWF Kankerbestrijding, including a Queen Wilhelmina Award program), and Vidi and Vici grants from the Netherlands Organization for Scientific Research (NWO) to L.C.W.V., P.A.P., C.M., M.A.S., and D.S.P.

\section{References}

Alimonti A, Nardella C, Chen Z, Clohessy JG, Carracedo A, Trotman LC, Cheng K, Varmeh S, Kozma SC, Thomas G, et al. 2010. A novel type of cellular senescence that can be enhanced in mouse models and human tumor xenografts to suppress prostate tumorigenesis. J Clin Invest 120: 681-693.

Atefi M, von Euw E, Attar N, Ng C, Chu C, Guo D, Nazarian R, Chmielowski B, Glaspy JA, Comin-Anduix B, et al. 2011. Reversing melanoma cross-resistance to BRAF and MEK inhibitors by co-targeting the AKT/mTOR pathway. PLOS ONE 6: e28973. doi: 10.1371/journal.pone.0028973.

Bauer J, Curtin JA, Pinkel D, Bastian BC. 2007. Congenital melanocytic nevi frequently harbor NRAS mutations but no BRAF mutations. J Invest Dermatol 127: 179-182.

Bennett DC. 2003. Human melanocyte senescence and melanoma susceptibility genes. Oncogene 22: 3063-3069.

Bevona C, Goggins W, Quinn T, Fullerton J, Tsao H. 2003. Cutaneous melanomas associated with nevi. Arch Dermatol 139: $1620-1624$.

Birck A, Ahrenkiel V, Zeuthen J, Hou-Jensen K, Guldberg P. 2000. Mutation and allelic loss of the PTEN/MMAC1 gene in primary and metastatic melanoma biopsies. I Invest Dermatol 114: 277-280.

Bogdan I, Smolle J, Kerl H, Burg G, Boni R. 2003. Melanoma ex naevo: A study of the associated naevus. Melanoma Res 13: 213-217.

Brenner AJ, Stampfer MR, Aldaz CM. 1998. Increased p16 expression with first senescence arrest in human mammary epithelial cells and extended growth capacity with p16 inactivation. Oncogene 17: 199-205.

Ceol CI, Houvras Y, Jane-Valbuena J, Bilodeau S, Orlando DA, Battisti V, Fritsch L, Lin WM, Hollmann TJ, Ferre F, et al. 2011. The histone methyltransferase SETDB1 is recurrently amplified in melanoma and accelerates its onset. Nature 471: 513-517.

Chen Z, Trotman LC, Shaffer D, Lin HK, Dotan ZA, Niki M, Koutcher JA, Scher HI, Ludwig T, Gerald W, et al. 2005. Crucial role of p53-dependent cellular senescence in suppression of Pten-deficient tumorigenesis. Nature 436: 725-730.

Cheung M, Sharma A, Madhunapantula SV, Robertson GP. 2008. Akt3 and mutant V600E B-Raf cooperate to promote early melanoma development. Cancer Res 68: 3429-3439.

Collado M, Serrano M. 2010. Senescence in tumours: Evidence from mice and humans. Nat Rev Cancer 10: 51-57.

Courtois-Cox S, Genther Williams SM, Reczek EE, Johnson BW, McGillicuddy LT, Johannessen CM, Hollstein PE, MacCollin M, Cichowski K. 2006. A negative feedback signaling network underlies oncogene-induced senescence. Cancer Cell 10: 459-472.

Curtin JA, Fridlyand J, Kageshita T, Patel HN, Busam KJ, Kutzner H, Cho KH, Aiba S, Brocker EB, LeBoit PE, et al. 2005. Distinct sets of genetic alterations in melanoma. $N$ Engl I Med 353: 2135-2147.

Dadzie OE, Yang S, Emley A, Keady M, Bhawan J, Mahalingam M. 2009. RAS and RAF mutations in banal melanocytic aggregates contiguous with primary cutaneous melanoma: Clues to melanomagenesis. Br J Dermatol 160: 368-375.

Dai DL, Martinka M, Li G. 2005. Prognostic significance of activated Akt expression in melanoma: A clinicopathologic study of 292 cases. J Clin Oncol 23: 1473-1482. 
Daniotti M, Oggionni M, Ranzani T, Vallacchi V, Campi V, Di Stasi D, Torre GD, Perrone F, Luoni C, Suardi S, et al. 2004. BRAF alterations are associated with complex mutational profiles in malignant melanoma. Oncogene 23: 5968-5977.

Dankort D, Filenova E, Collado M, Serrano M, Jones K, McMahon M. 2007. A new mouse model to explore the initiation, progression, and therapy of BRAFV600E-induced lung tumors. Genes Dev 21: 379-384.

Dankort D, Curley DP, Cartlidge RA, Nelson B, Karnezis AN, Damsky WE Jr, You MJ, Depinho RA, McMahon M, Bosenberg M. 2009. Braf(V600E) cooperates with Pten loss to induce metastatic melanoma. Nat Genet 41: 544-552.

Davies H, Bignell GR, Cox C, Stephens P, Edkins S, Clegg S, Teague J, Woffendin H, Garnett MJ, Bottomley W, et al. 2002. Mutations of the BRAF gene in human cancer. Nature 417: 949-954.

Davies MA, Stemke-Hale K, Tellez C, Calderone TL, Deng W, Prieto VG, Lazar AJ, Gershenwald JE, Mills GB. 2008. A novel AKT3 mutation in melanoma tumours and cell lines. Br J Cancer 99: 1265-1268.

Demunter A, Stas M, Degreef H, De Wolf-Peeters C, van den Oord JJ. 2001. Analysis of N- and K-ras mutations in the distinctive tumor progression phases of melanoma. I Invest Dermatol 117: 1483-1489.

Denoyelle C, Abou-Rjaily G, Bezrookove V, Verhaegen M, Johnson TM, Fullen DR, Pointer JN, Gruber SB, Su LD, Nikiforov MA, et al. 2006. Anti-oncogenic role of the endoplasmic reticulum differentially activated by mutations in the MAPK pathway. Nat Cell Biol 8: 1053-1063.

Dhawan P, Singh AB, Ellis DL, Richmond A. 2002. Constitutive activation of Akt/protein kinase B in melanoma leads to upregulation of nuclear factor- $\mathrm{kB}$ and tumor progression. Cancer Res 62: 7335-7342.

Dhomen N, Reis-Filho JS, da Rocha Dias S, Hayward R, Savage K, Delmas V, Larue L, Pritchard C, Marais R. 2009. Oncogenic Braf induces melanocyte senescence and melanoma in mice. Cancer Cell 15: 294-303.

Forbes S, Clements J, Dawson E, Bamford S, Webb T, Dogan A, Flanagan A, Teague J, Wooster R, Futreal PA, et al. 2006. Cosmic 2005. Br J Cancer 94: 318-322.

Freeman DJ, Li AG, Wei G, Li HH, Kertesz N, Lesche R, Whale $\mathrm{AD}$, Martinez-Diaz H, Rozengurt N, Cardiff RD, et al. 2003. PTEN tumor suppressor regulates p53 protein levels and activity through phosphatase-dependent and -independent mechanisms. Cancer Cell 3: 117-130.

Garraway LA, Widlund HR, Rubin MA, Getz G, Berger AJ, Ramaswamy S, Beroukhim R, Milner DA, Granter SR, Du J, et al. 2005. Integrative genomic analyses identify MITF as a lineage survival oncogene amplified in malignant melanoma. Nature 436: 117-122.

Goel VK, Ibrahim N, Jiang G, Singhal M, Fee S, Flotte T, Westmoreland S, Haluska FS, Hinds PW, Haluska FG. 2009. Melanocytic nevus-like hyperplasia and melanoma in transgenic BRAFV600E mice. Oncogene 28: 2289-2298.

Gray-Schopfer VC, Cheong SC, Chong H, Chow J, Moss T, Abdel-Malek ZA, Marais R, Wynford-Thomas D, Bennett DC. 2006. Cellular senescence in naevi and immortalisation in melanoma: A role for p16? Br J Cancer 95: 496-505.

Guldberg P, thor Straten P, Birck A, Ahrenkiel V, Kirkin AF, Zeuthen J. 1997. Disruption of the MMAC1/PTEN gene by deletion or mutation is a frequent event in malignant melanoma. Cancer Res 57: 3660-3663.

Haferkamp S, Scurr LL, Becker TM, Frausto M, Kefford RF, Rizos H. 2009. Oncogene-induced senescence does not require the p16(INK4a) or p14ARF melanoma tumor suppressors. I Invest Dermatol 129: 1983-1991.
Kamb A, Gruis NA, Weaver-Feldhaus J, Liu Q, Harshman K, Tavtigian SV, Stockert E, Day RS III, Johnson BE, Skolnick MH. 1994. A cell cycle regulator potentially involved in genesis of many tumor types. Science 264: 436-440.

Karreth FA, Tay Y, Perna D, Ala U, Tan SM, Rust AG, DeNicola G, Webster KA, Weiss D, Perez-Mancera PA, et al. 2011. In vivo identification of tumor-suppressive PTEN ceRNAs in an oncogenic BRAF-induced mouse model of melanoma. Cell 147: 382-395.

Kennedy AL, Morton JP, Manoharan I, Nelson DM, Jamieson NB, Pawlikowski JS, McBryan T, Doyle B, McKay C, Oien $\mathrm{KA}$, et al. 2011. Activation of the PIK3CA/AKT pathway suppresses senescence induced by an activated RAS oncogene to promote tumorigenesis. Mol Cell 42: 36-49.

Kuilman T, Michaloglou C, Mooi WJ, Peeper DS. 2010. The essence of senescence. Genes Dev 24: 2463-2479.

Lin WM, Baker AC, Beroukhim R, Winckler W, Feng W, Marmion JM, Laine E, Greulich H, Tseng H, Gates C, et al. 2008. Modeling genomic diversity and tumor dependency in malignant melanoma. Cancer Res 68: 664-673.

Marone R, Erhart D, Mertz AC, Bohnacker T, Schnell C, Cmiljanovic V, Stauffer F, Garcia-Echeverria C, Giese B, Maira SM, et al. 2009. Targeting melanoma with dual phosphoinositide 3-kinase/mammalian target of rapamycin inhibitors. Mol Cancer Res 7: 601-613.

Michaloglou C, Vredeveld LC, Soengas MS, Denoyelle C, Kuilman T, van der Horst CM, Majoor DM, Shay JW, Mooi WI, Peeper DS. 2005. BRAFE600-associated senescence-like cell cycle arrest of human naevi. Nature 436: 720-724.

Mirmohammadsadegh A, Marini A, Nambiar S, Hassan M, Tannapfel A, Ruzicka T, Hengge UR. 2006. Epigenetic silencing of the PTEN gene in melanoma. Cancer Res 66: 65466552.

Mooi WJ, Krausz T. 2007. Pathology of melanocytic disorders. Hodder Arnold, London.

Mooi WJ, Peeper DS. 2006. Oncogene-induced cell senescencehalting on the road to cancer. N Engl J Med 355: 1037-1046.

Nardella C, Clohessy JG, Alimonti A, Pandolfi PP. 2011. Prosenescence therapy for cancer treatment. Nat Rev Cancer 11: 503-511.

Nobori T, Miura K, Wu DJ, Lois A, Takabayashi K, Carson DA. 1994. Deletions of the cyclin-dependent kinase-4 inhibitor gene in multiple human cancers. Nature 368: 753-756.

Omholt K, Krockel D, Ringborg U, Hansson J. 2006. Mutations of PIK3CA are rare in cutaneous melanoma. Melanoma Res 16: 197-200.

Palavalli LH, Prickett TD, Wunderlich JR, Wei X, Burrell AS, Porter-Gill P, Davis S, Wang C, Cronin JC, Agrawal NS, et al. 2009. Analysis of the matrix metalloproteinase family reveals that MMP8 is often mutated in melanoma. Nat Genet 41: 518-520.

Paraiso KH, Xiang Y, Rebecca VW, Abel EV, Chen YA, Munko AC, Wood E, Fedorenko IV, Sondak VK, Anderson AR, et al. 2011. PTEN loss confers BRAF inhibitor resistance to melanoma cells through the suppression of BIM expression. Cancer Res 71: 2750-2760.

Pavel S, Smit NP, van der Meulen H, Kolb RM, de Groot AJ, van der Velden PA, Gruis NA, Bergman W. 2003. Homozygous germline mutation of CDKN2A/p16 and glucose-6-phosphate dehydrogenase deficiency in a multiple melanoma case. Melanoma Res 13: 171-178.

Pollock PM, Harper UL, Hansen KS, Yudt LM, Stark M, Robbins CM, Moses TY, Hostetter G, Wagner U, Kakareka J, et al. 2003. High frequency of BRAF mutations in nevi. Nat Genet 33: $19-20$. 
Prickett TD, Agrawal NS, Wei X, Yates KE, Lin JC, Wunderlich JR, Cronin JC, Cruz P, Rosenberg SA, Samuels Y. 2009. Analysis of the tyrosine kinome in melanoma reveals recurrent mutations in ERBB4. Nat Genet 41: 1127-1132.

Prickett TD, Wei X, Cardenas-Navia I, Teer JK, Lin JC, Walia V, Gartner J, Jiang J, Cherukuri PF, Molinolo A, et al. 2011. Exon capture analysis of $\mathrm{G}$ protein-coupled receptors identifies activating mutations in GRM3 in melanoma. Nat Genet 43: 1119-1126.

Raybaud F, Noguchi T, Marics I, Adelaide J, Planche J, Batoz M, Aubert C, de Lapeyriere O, Birnbaum D. 1988. Detection of a low frequency of activated ras genes in human melanomas using a tumorigenicity assay. Cancer Res 48: 950-953.

Shao Y, Aplin AE. 2010. Akt3-mediated resistance to apoptosis in B-RAF-targeted melanoma cells. Cancer Res 70: 66706681.

Smolle J, Kaddu S, Kerl H. 1999. Non-random spatial association of melanoma and naevi-a morphometric analysis. Melanoma Res 9: 407-412.

Stahl JM, Sharma A, Cheung M, Zimmerman M, Cheng JQ, Bosenberg MW, Kester M, Sandirasegarane L, Robertson GP. 2004. Deregulated Akt3 activity promotes development of malignant melanoma. Cancer Res 64: 7002-7010.

Stolz W, Schmoeckel C, Landthaler M, Braun-Falco O. 1989. Association of early malignant melanoma with nevocytic nevi. Cancer 63: 550-555.

Tsao H, Zhang X, Fowlkes K, Haluska FG. 2000. Relative reciprocity of NRAS and PTEN/MMAC1 alterations in cutaneous melanoma cell lines. Cancer Res 60: 1800-1804.

Tsao H, Mihm MC Jr, Sheehan C. 2003. PTEN expression in normal skin, acquired melanocytic nevi, and cutaneous melanoma. J Am Acad Dermatol 49: 865-872.

Tsao H, Goel V, Wu H, Yang G, Haluska FG. 2004. Genetic interaction between NRAS and BRAF mutations and PTEN/ MMAC1 inactivation in melanoma. I Invest Dermatol 122: 337-341.

van't Veer LJ, Burgering BM, Versteeg R, Boot AJ, Ruiter DJ, Osanto S, Schrier PI, Bos JL. 1989. N-ras mutations in human cutaneous melanoma from sun-exposed body sites. Mol Cell Biol 9: 3114-3116.

Wei X, Walia V, Lin JC, Teer JK, Prickett TD, Gartner J, Davis S, Stemke-Hale K, Davies MA, Gershenwald JE, et al. 2011. Exome sequencing identifies GRIN2A as frequently mutated in melanoma. Nat Genet 43: 442-446.

Whiteman DC, Zhou XP, Cummings MC, Pavey S, Hayward NK, Eng C. 2002. Nuclear PTEN expression and clinicopathologic features in a population-based series of primary cutaneous melanoma. Int I Cancer 99: 63-67.

Yazdi AS, Palmedo G, Flaig MJ, Puchta U, Reckwerth A, Rutten A, Mentzel T, Hugel H, Hantschke M, Schmid-Wendtner $\mathrm{MH}$, et al. 2003. Mutations of the BRAF gene in benign and malignant melanocytic lesions. J Invest Dermatol 121: 11601162.

Yokoyama S, Woods SL, Boyle GM, Aoude LG, MacGregor S, Zismann V, Gartside M, Cust AE, Haq R, Harland M, et al. 2011. A novel recurrent mutation in MITF predisposes to familial and sporadic melanoma. Nature 480: 99-103.

Zhou XP, Gimm O, Hampel H, Niemann T, Walker MJ, Eng C. 2000. Epigenetic PTEN silencing in malignant melanomas without PTEN mutation. Am I Pathol 157: 1123-1128. 


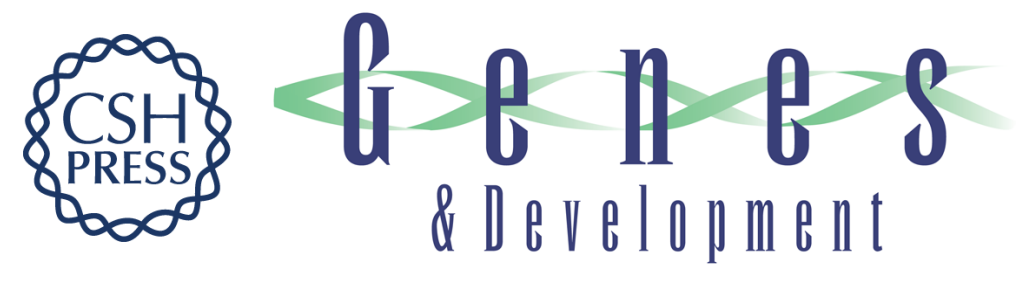

\section{Abrogation of BRAFV600E -induced senescence by PI3K pathway activation contributes to melanomagenesis}

Liesbeth C.W. Vredeveld, Patricia A. Possik, Marjon A. Smit, et al.

Genes Dev. 2012, 26: originally published online May 1, 2012

Access the most recent version at doi:10.1101/gad.187252.112

Supplemental http://genesdev.cshlp.org/content/suppl/2012/04/23/gad.187252.112.DC1
Material

References This article cites 64 articles, 16 of which can be accessed free at: http://genesdev.cshlp.org/content/26/10/1055.full.html\#ref-list-1

License

Email Alerting

Service
Receive free email alerts when new articles cite this article - sign up in the box at the top right corner of the article or click here.

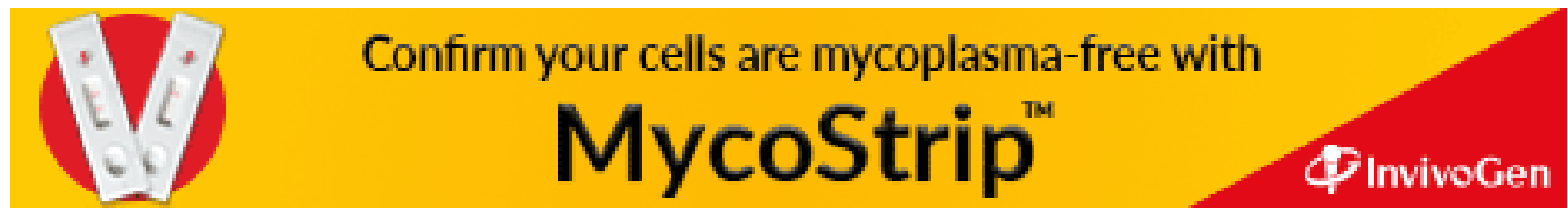

